\title{
Variation of volcanic gas composition during the eruptive period in 2014-2015 at Nakadake crater, Aso volcano, Japan
}

\author{
Hiroshi Shinohara ${ }^{{ }^{*}}$ (D) , Akihiko Yokoo ${ }^{2}$ and Ryunosuke Kazahaya ${ }^{1}$
}

\begin{abstract}
Volcanic gas composition measurement by Multi-GAS was repeated during the eruptive period in 2014-2015 as well as the quiet period preceding the eruption at Nakadake crater, Aso volcano. The eruptive activity is characterized by continuous ash emission with intermittent Strombolian activity and temporal pauses. Volcanic gas composition measured during the eruptive period showed a rapid and large variation. In particular, the $\mathrm{CO}_{2} / \mathrm{SO}_{2}$ and $\mathrm{SO}_{2} / \mathrm{H}_{2} \mathrm{~S}$ ratios varied in the rages of 1-8 and 3-300 during the ash eruption with a clear negative correlation. The large variation and the negative correlation of the compositions are attributed to two orders of magnitude difference of degassing pressure, such as 20 and $0.2 \mathrm{MPa}$; the gases with the large $\mathrm{CO}_{2} / \mathrm{SO}_{2}$ and the small $\mathrm{SO}_{2} / \mathrm{H}_{2} \mathrm{~S}$ ratios are derived from the high pressure. The rapid and large composition variation suggests frequent ascent of bubbles formed at various depth during the eruption. The maximum $\mathrm{CO}_{2} / \mathrm{SO}_{2}$ ratio decreased with decreasing eruption intensity that suggests decrease in contribution of the bubbles derived from a large depth. With time, $\mathrm{H}_{2} \mathrm{O} / \mathrm{SO}_{2}$ ratio of the gases increases from 30 to $>60$, suggesting increase in a hydrothermal contribution.
\end{abstract}

Keywords: Aso volcano, Eruption, Volcanic gas, Multi-GAS, Degassing

\section{Introduction}

Expansion of bubbles in magmas is the major driving force of explosive eruptions, and behavior of bubbles in magmas controls variation of eruption styles. Volcanic gas composition constraints conditions of bubble formation and separation of bubbles from magmas. Composition of gases discharged during eruption, however, was poorly known in the past because of the difficulty of gas sampling from an erupting vent. Recent development of gas monitoring techniques enabled composition measurement of volcanic gases discharged during eruptions and has revealed the role of bubbles in magmas during eruptions. Emission of $\mathrm{CO}_{2}$-rich gases measured during Strombolian and lava fountaining eruptions by Fourier transform infrared absorption spectroscopy (FT-IR) revealed that these eruptions are driven by $\mathrm{CO}_{2}$-rich

\footnotetext{
${ }^{*}$ Correspondence: shinohara-h@aist.go.jp

${ }^{1}$ Geological Survey of Japan, National Institute of Advanced Industrial Science and Technology, 1-1-1 Higashi, Tsukuba, Ibaraki 305-8567, Japan Full list of author information is available at the end of the article
}

bubbles formed at a high pressure (Allard et al. 2005; Burton et al. 2007). Increase in $\mathrm{CO}_{2} / \mathrm{SO}_{2}$ ratio of volcanic gases was observed by Multi-GAS measurement prior to paroxysmal explosions at Stromboli and Villarrica volcanoes and is attributed to supply of $\mathrm{CO}_{2}$-rich bubbles formed at a high pressure (Aiuppa et al. 2009, 2017). These examples suggest that supply of $\mathrm{CO}_{2}$-rich bubbles drives eruptions; however, there is few measurement of the gas composition during eruptions other than Strombolian or lava fountaining eruptions. Variation of $\mathrm{CO}_{2} /$ $\mathrm{SO}_{2}$ ratio in volcanic gases was not detected at Asama volcano before and after vulcanian eruptions but the composition data during the eruption were not obtained (Shinohara et al. 2015a).

Nakadake crater, Aso volcano, is a persistently degassing volcano with frequent magmatic eruptions, which are characterized by continuous ash eruption with intermittent Strombolian activity (Ono et al. 1995; Sudo et al. 2006). Volcanic gas composition measurement is repeated using Multi-GAS since 2003 (Shinohara et al. 2015b). This article reports results of the recent 
measurement including a period of recent eruptions in 2014-2015. The recent eruptive activity is the typical activity of the volcano, and gas measurement was performed during ash eruptions with variable intensities and during temporal pauses of the eruptions. Conditions to cause observed gas composition variation are evaluated in relation to variation of the eruptive activities. Gas composition variation is measured also during a quiet period before the eruption, and changes in gas supply processes during the quiet period and the eruptive period are discussed.

\section{Aso volcano}

Aso volcano is a large caldera volcano, with the size of $25 \mathrm{~km}$ north-south and $18 \mathrm{~km}$ east-west, and repeated gigantic pyroclastic flow eruptions from 270 to $90 \mathrm{ka}$. Several post-caldera cones, with compositions ranging from basalt to rhyolite, are formed near the center of the caldera after the last caldera forming eruption (Ono and Watanabe 1985). Nakadake cone is a presently active basalt to basaltic-andesitic stratocone of Aso volcano (Fig. 1 map). During the past 6000 years, dominant eruptive products at Nakadake cone are black ash with some scoria, indicating that the foremost eruption style was continuous ash emission, that is called "ash eruption" (Ono et al. 1995). The Nakadake cone is currently quite active with ash eruptions in 1974, 1979, 1984-1985, 1985-1995 and 2014-2015 (Ikebe et al. 2008; Ono et al. 1995; Yokoo and Miyabuchi 2015).
During quiet stages of the volcano, the summit crater of Nakadake cone is filled with a hot and acid crater lake with water temperature ranging $40-80{ }^{\circ} \mathrm{C}$ and acidity levels of $\mathrm{pH}=-1$ to +1 (Ohsawa et al. 2003, 2010; Miyabuchi and Terada 2009). The Nakadake crater repeated a cyclic activity as follows (Kawakatsu et al. 2000; Sudo et al. 2006): When the lake water level becomes low, phreatic eruptions occur. After the lake completely dries, high-temperature gas vents appear at the bottom with incandescence, then start to emit volcanic ashes. With widening of the vent, the ash eruption becomes continuous and intense, and is associated with intermittent Strombolian explosions. The crater lake water recovers with weakening of the magmatic eruptive activity (Sudo et al. 2006).

The most recent magmatic eruption started on November 27, 2014, with continuous ash eruption and intermittent Strombolian explosions that continued until May 21, 2015, with temporal pauses of the ash emissions. Variation of the crater lake volume, $\mathrm{SO}_{2}$ flux from the crater and related activities between 2000 and 2016 are reported by Fukuoka Regional Headquarters, Japan Meteorological Agency (2016) and Terada and Hashimoto (2017). The lake water was at $100 \%$ level in 2009 , decreased to a low level for a few times in 2010, 2011 and 2012, then almost dried at the end of 2013 and fumaroles appeared at the crater bottom. The $\mathrm{SO}_{2}$ flux was about $500 \mathrm{t} / \mathrm{d}$ before 2013 and increased to $500-2000 \mathrm{t} / \mathrm{d}$ in the late 2013 after drying of the crater lake water. Temperature of fumaroles at the crater bottom increased, a

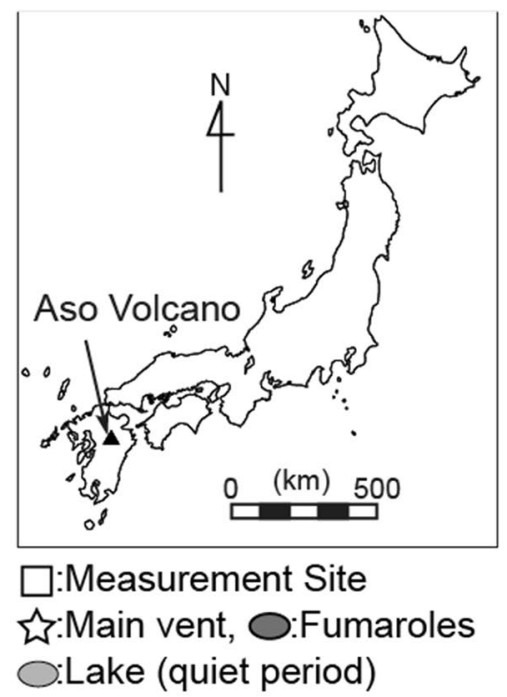

b

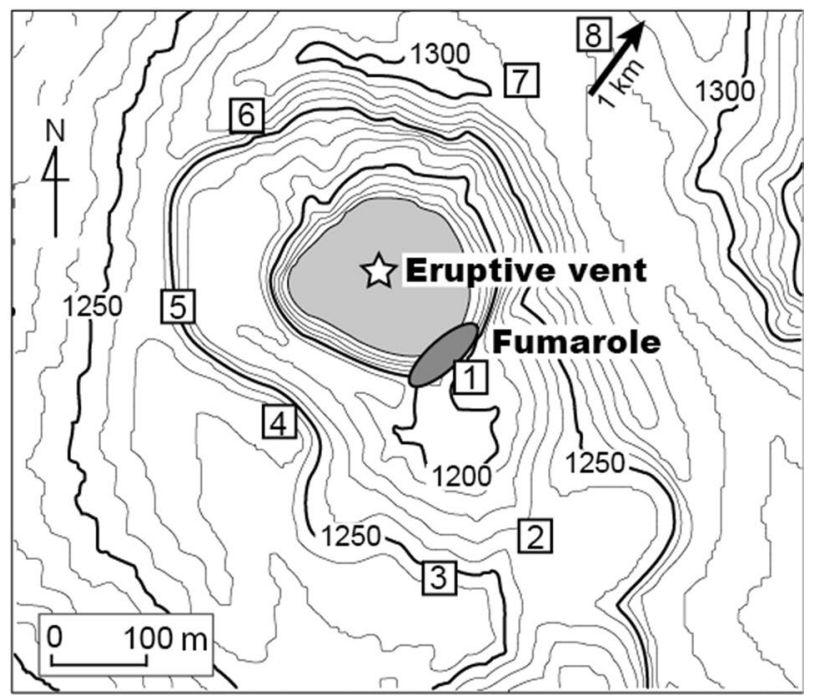

Fig. 1 Location maps. a The location of Aso volcano in Japan; $\mathbf{b}$ distribution of the Yudamari crater lake and the fumarolic area at the southern wall of the summit crater of Nakadake central cone, Aso volcano. Contours are in 10-m intervals. The numbers in squares indicate the locations of plume measurement (Table 1). The location 8 is located further $1 \mathrm{~km}$ to the northeast from the point on the map 
and incandescence was observed even in the daylight on November 18, 2014. The eruption started from the hightemperature vent on November 25 and became intensive with enlargement of the vent (Yokoo and Miyabuchi 2015). The eruption style is the continuous ash eruption with intermittent Strombolian explosions, similar to the past eruptions. The ash eruption culminated in late January, discharging $\sim 2 \times 10^{6}$ tons of ash until February 2, 2015 (Marumoto et al. 2017; Yokoo and Miyabuchi 2015). The $\mathrm{SO}_{2}$ flux increased to $1000-3000 \mathrm{t} / \mathrm{d}$ during the most active period. The eruption continued with some temporal pauses until May 21, 2015. After the cease of the eruption in May 2015, the crater lake water immediately recovered by June 6,2015 , but the $\mathrm{SO}_{2}$ flux continued to be high as 1000-2000 t/d until present (August, 2017).

Gas emission occurs at two locations in the Nakadake crater: fumaroles on the southern wall of the crater and center area of the crater (Fig. 1b). During the quiet stage, the crater is filled with the hot and acid lake water and intensive gas emission occurs through the lake water (lake gas; Fig. 2a; Shinohara et al. 2015b). After drying the lake, fumaroles appeared at the center of the crater floor (Fig. 2b). The eruption started from one of the intense fumaroles, which became a single location of eruption and degassing on the crater floor. The main vent discharges volcanic gases not only during the ash eruption but also during temporal pauses of the eruption (vent gas; Fig. 2c-g). Degassing from the southern fumaroles (fumarolic gas) was continuous regardless of the changes from the quiet period to the eruptive period.

Variation of volcanic gas compositions of the lake gas and the fumarolic gas at the southern wall until March 2009 was reported by Shinohara et al. (2015b). The fumarolic gases have a typical magmatic gas composition with high $\mathrm{SO}_{2}$ and $\mathrm{H}_{2}$ contents and have high equilibrium temperatures estimated based on their chemical and isotopic composition up to $900{ }^{\circ} \mathrm{C}$, suggesting that the fumarolic gases are directly derived from magma degassing
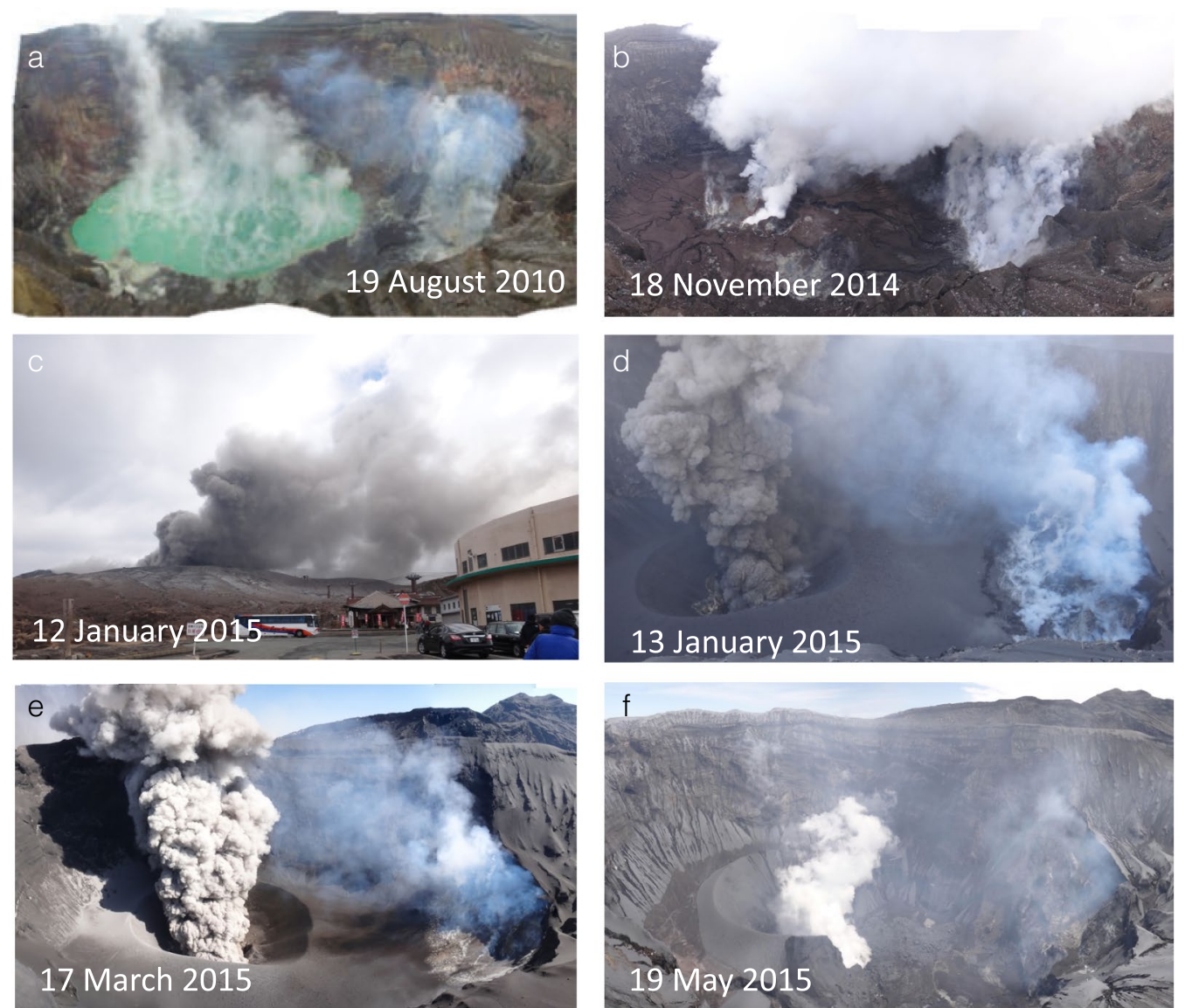

Fig. 2 Photographs of the degassing and eruptive activities at the Nakadake crater, Aso volcano. All photographs, except c, were taken from the location 4 in Fig. 1, and show the two separate degassing sources of the main vent (or the crater lake) on the left and the fumaroles on the southern rim on the right. a The crater lake and the fumarolic area during the quiet period on August 19, 2010. b Gas emission occurs at the main vent after disappearance of the crater lake and the fumaroles on November 18,2014. c Intensive ash eruption on January 12, 2015. $\mathbf{d}$ The intermediate ash eruption on January 13, 2015. e The weak ash eruption on March 17, 2015. f Gas emission from the main vent on May 19, 2015 
(Shinohara et al. 2015b; Tsunogai et al. 2011). The lake gases are poor in $\mathrm{HCl}$ and $\mathrm{H}_{2} \mathrm{~S}$ due to reaction in the lake water, but have high contents of $\mathrm{SO}_{2}$ and $\mathrm{H}_{2}$, indicating the magmatic gas supply also to the lake gas. The $\mathrm{CO}_{2} /$ $\mathrm{SO}_{2}$ ratios of the lake gas are smaller than those of the fumarolic gas, in most cases. Shinohara et al. (2015b) interpreted the contrasting compositions as the result of differentiation of the magmatic gas to a $\mathrm{CO}_{2}$-rich vapor phase and a $\mathrm{CO}_{2}$-poor liquid phase under a hydrothermal system. The fumarolic gas is the mixture of the magmatic gas and the $\mathrm{CO}_{2}$-rich vapor of the hydrothermal system and the gas components that remained in the $\mathrm{CO}_{2}$-poor liquid phase are the source of the lake gases.

The crater bottom is dry during the eruptive period. A hydrothermal system, however, is suggested to be located at shallow depth surrounding the eruption vent based on observations of salt fallouts during ash eruptions (Shinohara et al. 2018). Fallout of hollow salt shells was observed during and shortly after ash eruptions in 2015 . The chemical composition of the salt shells was similar to the salts formed by the drying of the crater lake water. The hollow structure of the shells suggests that they were formed by the heating of hydrothermal solution droplets suspended by a stream of the plume. The salt shells suggest the existence of a hydrothermal system beneath the crater floor, even during the course of magmatic eruptions.

\section{Methods}

Composition of volcanic gases discharged from the southern fumaroles, the crater lake surface (during the quiet period) or the main vent (during the eruptive period) are estimated by the plume measurement with the Multi-GAS and alkali filter pack techniques (Aiuppa et al. 2005; Shinohara 2005). The Multi-GAS instrument has a non-dispersive infrared $\mathrm{CO}_{2}-\mathrm{H}_{2} \mathrm{O}$ analyzer (LI840, LI-COR, Inc., Lincoln, USA), $\mathrm{SO}_{2}$ and $\mathrm{H}_{2} \mathrm{~S}$ electrochemical sensors (KTS-512 and KHS-5TA, respectively, Komyo Rikagaku K.K., Kawasaki, Japan) and a $\mathrm{H}_{2}$ semiconductor sensor (Model GM12s, Sensor Tech K.K., Rittou, Japan). Data are recorded at 1-s intervals. The gas analyzer and sensors were calibrated with standard gases before and after each field trip. The electrochemical $\mathrm{H}_{2} \mathrm{~S}$ sensors have significant cross-sensitivity, and a filter-type scrubber for $\mathrm{SO}_{2}$ (Type KP-SO2J, Komyo Rikagaku K.K., Kawasaki, Japan) was placed in front of the KHS-5TA sensor to reduce the cross-sensitivity to $\mathrm{SO}_{2}$ (Shinohara et al. 2011). Capacity of the scrubber is $1500 \mathrm{ppm}$ min, which can remove $\mathrm{SO}_{2}$ of $150 \mathrm{ppm}$ for $10 \mathrm{~min}$. The scrubber needs to be replaced after exposure to the plume with high $\mathrm{SO}_{2}$ concentration. Cross-sensitivity of the $\mathrm{H}_{2} \mathrm{~S}$ sensor to $\mathrm{SO}_{2}$ is about $0.1 \%$ with the scrubber that can quantify the $\mathrm{SO}_{2} / \mathrm{H}_{2} \mathrm{~S}$ ratio up to 1000 . The relative concentrations of $\mathrm{S}, \mathrm{Cl}$ and $\mathrm{F}$ were obtained using the alkali filter pack technique (Shinohara and Witter 2005). The effect of partial absorption of $\mathrm{H}_{2} \mathrm{~S}$ by the alkaline filters was corrected by the method described by Shinohara et al. (2011).

Concentration ratios of the gas species in the volcanic gas are estimated based on a slope of a linear correlation on a scatter plot of two gas species concentrations (Shinohara et al. 2011, Table 1). In order to reduce a highfrequency noise on the LI-COR data, a running average of $15 \mathrm{~s}$ are used for the data analyses. Sensor response time is different for the different types of sensors, and the data are plotted by shifting the time to obtain the maximum correlation; e.g., the $\mathrm{CO}_{2}$ data are plotted with the $\mathrm{SO}_{2}$ data obtained several seconds later to compensate the slower response of the $\mathrm{SO}_{2}$ sensor. Typical time lag between $\mathrm{CO}_{2}$ data and other gas data is, $7 \mathrm{~s}$ for $\mathrm{SO}_{2}$, $4 \mathrm{~s}$ for $\mathrm{H}_{2} \mathrm{~S}, 1 \mathrm{~s}$ for $\mathrm{H}_{2} \mathrm{O}$ and $10 \mathrm{~s}$ for $\mathrm{H}_{2}$ (Shinohara et al. 2011). One sigma errors of the estimated concentration ratios by the instruments are $\pm 5 \%$ for $\mathrm{CO}_{2} / \mathrm{SO}_{2}, \mathrm{SO}_{2} / \mathrm{H}_{2} \mathrm{~S}$ and $\mathrm{H}_{2} \mathrm{O} / \mathrm{SO}_{2}$ ratio, and $\pm 15 \%$ for $\mathrm{H}_{2} / \mathrm{SO}_{2}$ ratio. The large error of the $\mathrm{H}_{2} / \mathrm{SO}_{2}$ ratio is due to slower response of the $\mathrm{H}_{2}$ sensor than other sensors, particularly in the low concentration range below 1 ppm (Shinohara et al. 2011). Actual error on natural plume measurements depends on concentrations of volcanic gas species, speed of concentration changes and background fluctuation in the atmosphere. Typical errors of the plume measurements are $\pm 10 \%$ for the $\mathrm{CO}_{2} / \mathrm{SO}_{2}$ and $\mathrm{SO}_{2} / \mathrm{H}_{2} \mathrm{~S}$ ratios and $\pm 30 \%$ for the $\mathrm{H}_{2} / \mathrm{SO}_{2}$ ratio $( \pm 1 \sigma)$. The typical error on the $\mathrm{H}_{2} \mathrm{O}$ / $\mathrm{SO}_{2}$ ratio is $\pm 10 \%$ under a stable atmospheric condition, but the error on the $\mathrm{H}_{2} \mathrm{O} / \mathrm{SO}_{2}$ ratio becomes larger with a larger fluctuation of the atmospheric background $\mathrm{H}_{2} \mathrm{O}$ concentration. The analytical error of the alkali filters is $\pm 5 \%$ for both $\mathrm{SO}_{2} / \mathrm{Cl}$ and $\mathrm{F} / \mathrm{Cl}$ ratios $( \pm 1 \sigma)$.

During the quiet period, we estimated separately the composition of the fumarolic gas and the lake gas by selecting the measurement location considering the wind direction and the actual plume movement. The crater lake and the fumaroles are inaccessible because of the steep wall of the summit crater (Fig. 1b), and the plume measurement are conducted on the crater rim at locations indicated in Fig. 1b. During the quiet stage, we can safely access to various locations, including the southern rim of the crater near the fumaroles (site 1 in Fig. 1), which enables the separate measurement of the fumarolic gas from the lake gas (Fig. 1). Cross-contamination of these gases, however, can sporadically occur by changes in the local wind direction because of the adjacent location of these sources. In most cases, we can estimate a representative composition of each target gas by neglecting minor peaks with compositions clearly different from the target gas composition (Table 1). These peaks with 
Table 1 Estimated gas composition

\begin{tabular}{|c|c|c|c|c|c|c|c|c|c|}
\hline \multirow{2}{*}{$\begin{array}{l}\text { Date } \\
\text { (yy/mm/dd) }\end{array}$} & \multicolumn{2}{|l|}{ Site } & \multirow{2}{*}{$\begin{array}{l}\mathrm{CO}_{2} / \mathrm{SO}_{2} \\
\text { (mol ratio) }\end{array}$} & \multirow[t]{2}{*}{$\mathrm{H}_{2} \mathrm{O} / \mathrm{SO}_{2}$} & \multirow[t]{2}{*}{$\mathrm{H}_{2} / \mathrm{SO}_{2}$} & \multirow[t]{2}{*}{$\mathrm{SO}_{2} / \mathrm{H}_{2} \mathrm{~S}$} & \multirow[t]{2}{*}{$\mathrm{SO}_{2} / \mathrm{Cl}$} & \multirow[t]{2}{*}{$\mathrm{Cl} / \mathrm{F}$} & \multirow[t]{2}{*}{ AETS $\left({ }^{\circ} \mathrm{C}\right)$} \\
\hline & No. & Note & & & & & & & \\
\hline \multicolumn{10}{|l|}{ Fumarolic gas } \\
\hline $15 / 10 / 2003$ & 3 & & 5.0 & $26^{\mathrm{a}}$ & - & - & 6.2 & 8.1 & \\
\hline 04/10/2004 & 2 & & 1.8 & 135 & - & $6.0^{\#}$ & 15 & 13 & - \\
\hline $26 / 10 / 2006$ & 2 & & 3.6 & $60^{\mathrm{a}}$ & 0.010 & 6.0 & 19 & - & 500 \\
\hline 19/09/2007 & 1 & & 4.8 & 43 & 0.28 & 13 & 11 & 3.7 & 890 \\
\hline $28 / 02 / 2008$ & 1 & & 2.2 & $20^{\mathrm{a}}$ & 0.11 & 20 & 11 & 2.5 & 890 \\
\hline 29/02/2008 & 1 & & 2.1 & $35^{\mathrm{a}}$ & 0.05 & 20 & 12 & 2.7 & 720 \\
\hline 10/07/2008 & 1 & e & 3.6 & $45^{\mathrm{a}}$ & 0.15 & 29 & 5.7 & 6.6 & 840 \\
\hline 10/07/2008 & 1 & $f$ & 2.2 & $50^{\mathrm{a}}$ & 0.07 & 23 & 4.8 & 8.0 & 720 \\
\hline $11 / 07 / 2008$ & 1 & e & 3.0 & $65^{\mathrm{a}}$ & 0.10 & 25 & 4.7 & 7.2 & 740 \\
\hline $11 / 07 / 2008$ & 1 & $f$ & 3.0 & $55^{\mathrm{a}}$ & 0.13 & 32 & 4.8 & 7.2 & 800 \\
\hline 28/10/2008 & 1 & & 1.7 & $40^{\mathrm{a}}$ & 0.15 & 31 & 9.0 & 4.3 & 860 \\
\hline 23/03/2009 & 1 & e & 4.0 & $70^{\mathrm{a}}$ & 0.13 & 19 & 7.9 & 5.4 & 740 \\
\hline 23/03/2009 & 1 & $f$ & 2.7 & $60^{\mathrm{a}}$ & 0.11 & 23 & 7.0 & 5.1 & 740 \\
\hline $19 / 11 / 2009$ & 1 & e & 4.3 & $50^{\mathrm{a}}$ & 0.33 & 12 & $12.5^{\mathrm{d}}$ & $3.4^{\mathrm{d}}$ & 900 \\
\hline $19 / 11 / 2009$ & 1 & $f$ & 3.0 & 44 & 0.36 & 17 & $12.5^{\mathrm{d}}$ & $3.4^{\mathrm{d}}$ & 950 \\
\hline 19/11/2009 & 1 & $g$ & 2.9 & 45 & 0.33 & 17 & $12.5^{\mathrm{d}}$ & $3.4^{d}$ & 930 \\
\hline 19/11/2009 & 1 & $\mathrm{~h}$ & 3.4 & 37 & 0.38 & 15 & $12.5^{\mathrm{d}}$ & $3.4^{\mathrm{d}}$ & 970 \\
\hline 06/07/2010 & 1 & & 3.2 & 47 & 0.010 & 8.6 & 6.5 & 7.0 & 530 \\
\hline $19 / 08 / 2010$ & 1 & & 4.5 & 89 & 0.05 & 7.0 & 5.0 & 8.5 & 600 \\
\hline $01 / 10 / 2010$ & 1 & & 4.7 & 70 & 0.03 & 6.5 & 9.0 & 20 & 560 \\
\hline 28/04/2011 & 1 & & 10.0 & 80 & 0.010 & 5.0 & 9.7 & 25 & 480 \\
\hline $05 / 12 / 2011$ & 1 & & 4.6 & $60^{a}$ & 0.013 & 13 & 120 & - & 540 \\
\hline $27 / 03 / 2012$ & 1 & & 4.5 & 40 & 0.024 & 5.0 & 7.9 & 6.7 & 590 \\
\hline $15 / 03 / 2013$ & 1 & & 5.3 & 40 & 0.07 & 6.0 & 13 & 5.2 & 700 \\
\hline 06/08/2013 & 1 & & 3.8 & $50^{\mathrm{a}}$ & 0.11 & 7.0 & 15 & 7.5 & 730 \\
\hline 07/10/2013 & 1 & & 6.2 & 50 & 0.20 & 6.5 & 13 & 3.8 & 790 \\
\hline $28 / 02 / 2014$ & 1 & K & 3.5 & 30 & 0.07 & 6.0 & $16^{d}$ & $4.0^{d}$ & 730 \\
\hline $28 / 02 / 2014$ & 1 & $\mathrm{~L}$ & 6.0 & $50^{\mathrm{a}}$ & 0.05 & 5.0 & $16^{d}$ & $4.0^{d}$ & 640 \\
\hline $06 / 06 / 2014$ & 1 & & 5.8 & 30 & 0.30 & 9.0 & 20 & 3.3 & 940 \\
\hline $18 / 11 / 2014$ & 1 & & 3.1 & 64 & 0.30 & 6.0 & 8.5 & 3.2 & 810 \\
\hline \multicolumn{10}{|l|}{ Lake Gas } \\
\hline 19/10/2003 & 4 & & 0.8 & - & - & - & 3.0 & 33 & - \\
\hline 04/10/2004 & 6 & & 1.9 & 66 & - & $70^{\#}$ & 107 & 1.6 & - \\
\hline $25 / 04 / 2005$ & 4 & & 1.2 & 34 & 0.06 & 6.5 & 5.0 & 90 & 700 \\
\hline $19 / 11 / 2005$ & 4 & & 2.3 & 56 & 0.05 & 59 & 210 & 1.3 & 710 \\
\hline $26 / 10 / 2006$ & 5 & & 2.2 & $50^{\mathrm{a}}$ & 0.020 & 50 & 100 & 18 & 620 \\
\hline $27 / 10 / 2006$ & 4 & & 2.6 & - & 0.010 & 60 & 26 & - & - \\
\hline 17/09/2007 & 5 & & 1.7 & $190^{\mathrm{a}}$ & 0.06 & 140 & 130 & 4.0 & 630 \\
\hline 18/09/2007 & 6 & & 2.0 & $120^{\mathrm{a}}$ & 0.05 & 85 & 44 & 3.1 & 640 \\
\hline $28 / 02 / 2008$ & 7 & & 1.4 & $80^{\mathrm{a}}$ & 0.06 & 170 & 40 & 3.3 & 740 \\
\hline $10 / 07 / 2008$ & 5 & & 1.3 & - & - & - & - & - & - \\
\hline $11 / 07 / 2008$ & 5 & & 0.8 & $70^{\mathrm{a}}$ & 0.05 & 100 & 79 & 15 & 710 \\
\hline 28/10/2008 & 5 & & 1.7 & $180^{\mathrm{a}}$ & 0.05 & 300 & 90 & 3.4 & 650 \\
\hline 23/03/2009 & 5 & & 1.0 & $90^{\mathrm{a}}$ & 0.030 & 2000 & 24 & 4.9 & 730 \\
\hline $24 / 03 / 2009$ & 5 & & 1.0 & $100^{\mathrm{a}}$ & 0.010 & 2000 & 28 & 9.0 & 610 \\
\hline 06/07/2010 & 5 & & 0.5 & 42 & 0.05 & 100 & 6.5 & 23 & 760 \\
\hline 19/08/2010 & 5 & & 0.7 & $80^{a}$ & 0.05 & 1000 & 13 & 17 & 780 \\
\hline
\end{tabular}


Table 1 (continued)

\begin{tabular}{|c|c|c|c|c|c|c|c|c|c|}
\hline \multirow{2}{*}{$\begin{array}{l}\text { Date } \\
\text { (yy/mm/dd) }\end{array}$} & \multicolumn{2}{|l|}{ Site } & \multirow{2}{*}{$\begin{array}{l}\mathrm{CO}_{2} / \mathrm{SO}_{2} \\
\text { (mol ratio) }\end{array}$} & \multirow[t]{2}{*}{$\mathrm{H}_{2} \mathrm{O} / \mathrm{SO}_{2}$} & \multirow[t]{2}{*}{$\mathrm{H}_{2} / \mathrm{SO}_{2}$} & \multirow[t]{2}{*}{$\mathrm{SO}_{2} / \mathrm{H}_{2} \mathrm{~S}$} & \multirow[t]{2}{*}{$\mathrm{SO}_{2} / \mathrm{Cl}$} & \multirow[t]{2}{*}{$\mathrm{Cl} / \mathrm{F}$} & \multirow[t]{2}{*}{$\operatorname{AETS}\left({ }^{\circ} \mathrm{C}\right)$} \\
\hline & No. & Note & & & & & & & \\
\hline 28/04/2011 & 5 & & 0.7 & 30 & 0.022 & 4.5 & 3.0 & 66 & 610 \\
\hline 19/05/2011 & 6 & K & 0.5 & $20^{\mathrm{a}}$ & 0.07 & 10 & $5.7^{d}$ & $8.0^{d}$ & 800 \\
\hline 19/05/2011 & 6 & $L$ & 1.0 & $45^{\mathrm{a}}$ & 0.04 & 7.0 & $5.7^{d}$ & $8.0^{d}$ & 640 \\
\hline 27/03/2012 & 5 & K & 0.34 & 54 & 0.08 & 200 & $55^{d}$ & $4.9^{d}$ & 820 \\
\hline 27/03/2012 & 5 & $L$ & 0.87 & $50^{\mathrm{a}}$ & 0.06 & 20 & $55^{d}$ & $4.9^{d}$ & 700 \\
\hline $15 / 03 / 2013$ & 5 & & 0.35 & 50 & 0.06 & 150 & 70 & 10 & 780 \\
\hline 06/08/2013 & 5 & & 0.7 & 80 & 0.08 & 40 & 10 & 23 & 710 \\
\hline 07/10/2013 & 5 & & 0.7 & 80 & 0.08 & 40 & 4.8 & 17 & 710 \\
\hline $28 / 02 / 2014$ & 5 & & 0.8 & - & 0.06 & 10 & 7.1 & 65 & - \\
\hline 06/06/2014 & 5 & & 0.6 & $50^{\mathrm{a}}$ & 0.20 & 60 & 8.1 & 3.2 & 900 \\
\hline $18 / 11 / 2014$ & 5 & & 1.0 & $40^{\mathrm{a}}$ & 0.05 & 500 & 11 & 2.2 & 840 \\
\hline \multicolumn{10}{|c|}{ During eruption } \\
\hline $12 / 01 / 2015$ & 3 & $A$ & 8.0 & 30 & 0.11 & 3.0 & - & - & 770 \\
\hline $12 / 01 / 2015$ & 3 & B & 1.6 & 30 & 0.11 & 40 & - & - & 870 \\
\hline $12 / 01 / 2015$ & 3 & C & 1.6 & 30 & 0.11 & 300 & - & - & 990 \\
\hline $25 / 02 / 2015$ & 8 & $B^{\prime}$ & 1.7 & 60 & 0.16 & 24 & 4.9 & - & 790 \\
\hline $17 / 03 / 2015$ & 6 & $A^{\prime \prime}$ & 4.0 & $400^{b}$ & 0.10 & 3.0 & $2.2^{d}$ & $5.1^{d}$ & 510 \\
\hline $17 / 03 / 2015$ & 6 & $\mathrm{~B}^{\prime \prime}$ & 1.6 & $70^{b}$ & 0.015 & 30 & $2.2^{d}$ & $5.1^{d}$ & 560 \\
\hline $17 / 03 / 2015$ & 6 & $C^{\prime \prime}$ & 1.6 & $70^{b}$ & 0.008 & 300 & $2.2^{d}$ & $5.1^{d}$ & 570 \\
\hline 19/05/2015 & 4 & & 3.2 & - & 0.007 & 6.5 & 57 & 11 & $440^{c}$ \\
\hline $20 / 05 / 2015$ & 2 & & 2.4 & - & 0.006 & 4.6 & 8.6 & 18 & $430^{c}$ \\
\hline $20 / 05 / 2015$ & 4 & & 3.5 & - & 0.011 & 3.4 & 6.8 & 20 & $440^{c}$ \\
\hline 20/05/2015 & 5 & & 2.4 & - & - & 5.7 & 4.6 & 12 & \\
\hline
\end{tabular}

$\mathrm{e}, \mathrm{f}, \mathrm{g}$ and $\mathrm{h}$ are results of sequential measurements within a single day. $\mathrm{K}$ and $\mathrm{L}$ are end-member compositions of variable composition obtained by a single measurement. A, B and C (and their prime and double prime) are representative compositions of the variable compositions observed in a day during the eruptive period (see text for details)

- not determine, \# Measured by the test tube (Komyo Rikagaku Kogyo Co.)

a The poor quality data with the correlation factor $<0.6$, due to large variation in the atmospheric $\mathrm{H} 2 \mathrm{O}$ concentration

b The poor quality data due to large variation in the atmospheric $\mathrm{H} 2 \mathrm{O}$ concentration

c Calculated with an assumption of $\mathrm{H}_{2} \mathrm{O} / \mathrm{SO}_{2}=100$

d A single AF sample collected during the multiple measurement of Multi-GAS

different compositions are likely derived from sporadic contamination of the gases from non-target sources. The effect of contamination on the alkaline-filter data, however, could not be removed because the filter sampled the plume during 30-60 min, and its results are an average composition during the sampling period.

During the eruptive period, it was not possible to perform the separate measurement of the gases from the different sources, i.e., the fumaroles and the eruptive vent, because of the limited access to avoid danger. The measured plume includes contribution from both sources. On January 12, February 25 and March 17, 2015, the measured plume compositions are quite variable during each observation. The scatter plots show quite large scattering and one or two representative concentration ratios cannot be estimated for each day based on the scatter plots (Additional file 1: Fig.
S1). The large scattering is likely due to temporal variation of the source gas composition or of contribution from different sources. In order to quantify the temporal variation, the gas concentration ratios are obtained by comparing peak concentration of each species at the time of major $\mathrm{SO}_{2}$ concentration peak (Additional file 2: Tables S1-S3). Typical errors of the peak concentration ratio for high $\mathrm{SO}_{2}$ peaks (such as $>10 \mathrm{ppm}$ ) are considered as similar to those obtained based on a linear correlation on scatter plots; $\pm 10 \%$ for the $\mathrm{CO}_{2} / \mathrm{SO}_{2}$ and $\mathrm{SO}_{2} / \mathrm{H}_{2} \mathrm{~S}$ ratios, $\pm 20 \%$ for the $\mathrm{H}_{2} \mathrm{O} / \mathrm{SO}_{2}$ ratio, and $\pm 30 \%$ for the $\mathrm{H}_{2} / \mathrm{SO}_{2}$ ratio $( \pm 1 \sigma)$. Larger errors might be associated with peaks with lower $\mathrm{SO}_{2}$ concentration.

In addition to the gas measurement, we observed infrasonic waves at a station of the crater rim (site 4 in Fig. 1) where no effect by topographic barriers should be considered for their propagation. The station was 
(See figure on next page.)

Fig. 3 A long-term variation of the gas concentration molar ratios from 2003 to $2015 . \mathbf{a ~} \mathrm{CO}_{2} / \mathrm{SO}_{2}$ molar ratio, $\mathbf{b} \mathrm{H}_{2} \mathrm{O} / \mathrm{SO}_{2}$ molar ratio, c SO$/$ $\mathrm{H}_{2}$ molar ratio, $\mathbf{d ~} \mathrm{SO}_{2} / \mathrm{Cl}$ molar ratio, $\mathbf{e ~} \mathrm{H}_{2} / \mathrm{SO}_{2}$ molar ratio and $\mathbf{f}$ Apparent equilibrium temperature. Circles and squares are the lake gas and the fumarolic gas compositions, respectively, and diamonds are the representative compositions during the eruptive period (Table 1, see text for details). Shadowed areas indicate the low lake volume periods

equipped with a low-frequency microphone (Datamark SI104; flat response in $0.1-1000 \mathrm{~Hz}$ ) and a digitizer (Datamark LS-8800) in which data were recorded into an SD card with a sampling frequency of $100 \mathrm{~Hz}$. The data had GPS-synchronized time stamps.

\section{Results \\ Quiet period}

Compositions of the fumarolic gas and the lake gas were separately estimated, but the effect of the cross-contamination can be recognized in some gases (Table 1). On 28 February 2014 (fumarolic gas), and 19 May 2011 and 27 March 2012 (lake gas), the scatter plots show large scattering between two ratios. In these cases, the two end-member ratios are estimated ( $\mathrm{K}$ and $\mathrm{L}$, Table 1 ). Variation of the composition is likely due to the cross-contamination of the fumarolic gas and the lake gas. During the period of high water level, the lake gas has smaller $\mathrm{CO}_{2} / \mathrm{SO}_{2}$ ratios and larger $\mathrm{SO}_{2} / \mathrm{H}_{2} \mathrm{~S}$ and $\mathrm{SO}_{2} / \mathrm{Cl}$ ratios than the fumarolic gas (Shinohara et al. 2015b). Mixing of the fumarolic gas to the lake gas results in a larger $\mathrm{CO}_{2} / \mathrm{SO}_{2}$ ratios and smaller $\mathrm{SO}_{2} /$ $\mathrm{H}_{2} \mathrm{~S}$ and $\mathrm{SO}_{2} / \mathrm{Cl}$ ratios than the lake gas. For an example, the $\mathrm{L}$ composition on 27 March 2012 has a larger $\mathrm{CO}_{2} / \mathrm{SO}_{2}$ ratio (0.87) and smaller $\mathrm{SO}_{2} / \mathrm{H}_{2} \mathrm{~S}$ ratio (20) than the $\mathrm{K}$ composition $\left(\mathrm{CO}_{2} / \mathrm{SO}_{2}=0.34\right.$ and $\mathrm{SO}_{2} / \mathrm{H}_{2} \mathrm{~S}$ ratio $\left.=200\right)$. The $\mathrm{L}$ composition is likely a composition affected by the mixing of the fumarolic gas to the $\mathrm{K}$ composition that is likely more representative of the lake gas composition. Large difference in the $\mathrm{SO}_{2} / \mathrm{Cl}$ ratios was obtained for the lake gas measured on subsequent days on 26 and 27 October 2006, and 17 and 18 September 2007. The large $\mathrm{SO}_{2} / \mathrm{Cl}$ ratios of $>100$ measured on the first day in both cases are likely the less-contaminated lake gases and the smaller ratios measured in the second day are caused by contamination of the fumarolic gas, as a mixing of the $\mathrm{HCl}$-rich fumarolic gases effectively decreases the $\mathrm{SO}_{2} / \mathrm{Cl}$ ratio.

On 10 and 11 July 2008, 23 March and 19 November 2009, multiple compositions are obtained by sequential measurements for the fumarolic gas (e, ee, g and $h$ on Table 1). The compositions have a variation slightly larger than the typical errors, up to twice of the errors. The variation in 10 and 11 July 2008, and 23 March 2009 is less likely due to the lake gas contamination, because a significant contribution of the lake gas with quite large $\mathrm{SO}_{2} / \mathrm{H}_{2} \mathrm{~S}$ ratio is not suggested from the small variation of the $\mathrm{SO}_{2} /$ $\mathrm{H}_{2} \mathrm{~S}$ ratio of the fumarolic gas. The variation larger than the typical error may imply the actual error under the real conditions or is a temporal or spatial variation in the fumarolic gas composition. Many fumaroles distribute along the southern wall of the crater and can cause the spatial variation.

Long-term variation of the lake gas and the fumarolic gas compositions have the features similar to those observed during 2003-2009 (Shinohara et al. 2015b; Fig. 3). The gas compositions did not show significant changes prior to the eruption, even on 18 November, only 10 days before the beginning of the eruption on November 27, 2014. The $\mathrm{CO}_{2} / \mathrm{SO}_{2}$ ratio of the lake gas ranges from 0.34 to 2.6 and that of the fumarolic gas ranges from 1.7 to 10 . These ratios symmetrically vary with a central value of about two; these gases have similar $\mathrm{CO}_{2} / \mathrm{SO}_{2}$ ratios when the ratios are close to two, and a larger deviation of the lake gas ratio from the central value to a large ratio occurs with a large deviation of the fumarolic gas ratio to a smaller ratio (Fig. 3a). The $\mathrm{H}_{2} \mathrm{O} / \mathrm{SO}_{2}$ ratio of the fumarolic gas does not show clear temporal variation with an average of $53 \pm 22(\mathrm{av} \pm 1 \sigma$, hereafter, error on an average is expressed in this form; Fig. $3 \mathrm{~b})$. The $\mathrm{H}_{2} \mathrm{O} / \mathrm{SO}_{2}$ ratio of the lake gas has the similar average of $55 \pm 18$ by excluding the poor quality data of the correlation factor $<0.6$ (Table 1). The fumarolic gas $\mathrm{SO}_{2} /$ $\mathrm{H}_{2} \mathrm{~S}$ ratio ranges from 5 to 30 , a common range for hightemperature volcanic gases (Giggenbach 1996) and shows a gradual increase in 2006-2008, then a gradual decrease in 2008-2011 (Fig. 3c). The lake gas $\mathrm{SO}_{2} / \mathrm{H}_{2} \mathrm{~S}$ ratio is from one to two orders of magnitude larger than the fumarolic gas, with exceptions of the low values during the low water level period. The large $\mathrm{SO}_{2} / \mathrm{H}_{2} \mathrm{~S}$ ratio in the lake gas is due to the reaction consuming $\mathrm{H}_{2} \mathrm{~S}$ to form elemental sulfur in the lake water (Shinohara et al. 2015b). The fumarolic gas $\mathrm{SO}_{2} /$ $\mathrm{Cl}$ ratio does not show clear temporal variation with an average of $10 \pm 4$ with excluding an outlier data on December 5, 2011 (Fig. 3d). The lake gas $\mathrm{SO}_{2} / \mathrm{Cl}$ ratio is commonly larger than the fumarolic gas, except for the low values during the low water level period. The large $\mathrm{SO}_{2} / \mathrm{Cl}$ ratio is due to efficient dissolution of $\mathrm{HCl}$ in the lake water, and the small ratio during the low water level period is caused by evaporation of the highly Cl-concentrated lake water (Shinohara et al. 2015b; Capaccioni et al. 2016).

The fumarolic gas $\mathrm{H}_{2} / \mathrm{SO}_{2}$ ratio shows a large variation ranging from 0.01 to 0.34 (Fig. 3e). The $\mathrm{H}_{2} / \mathrm{H}_{2} \mathrm{O}$ ratios in high-temperature volcanic gases are controlled by the following reaction (Giggenbach 1987): 

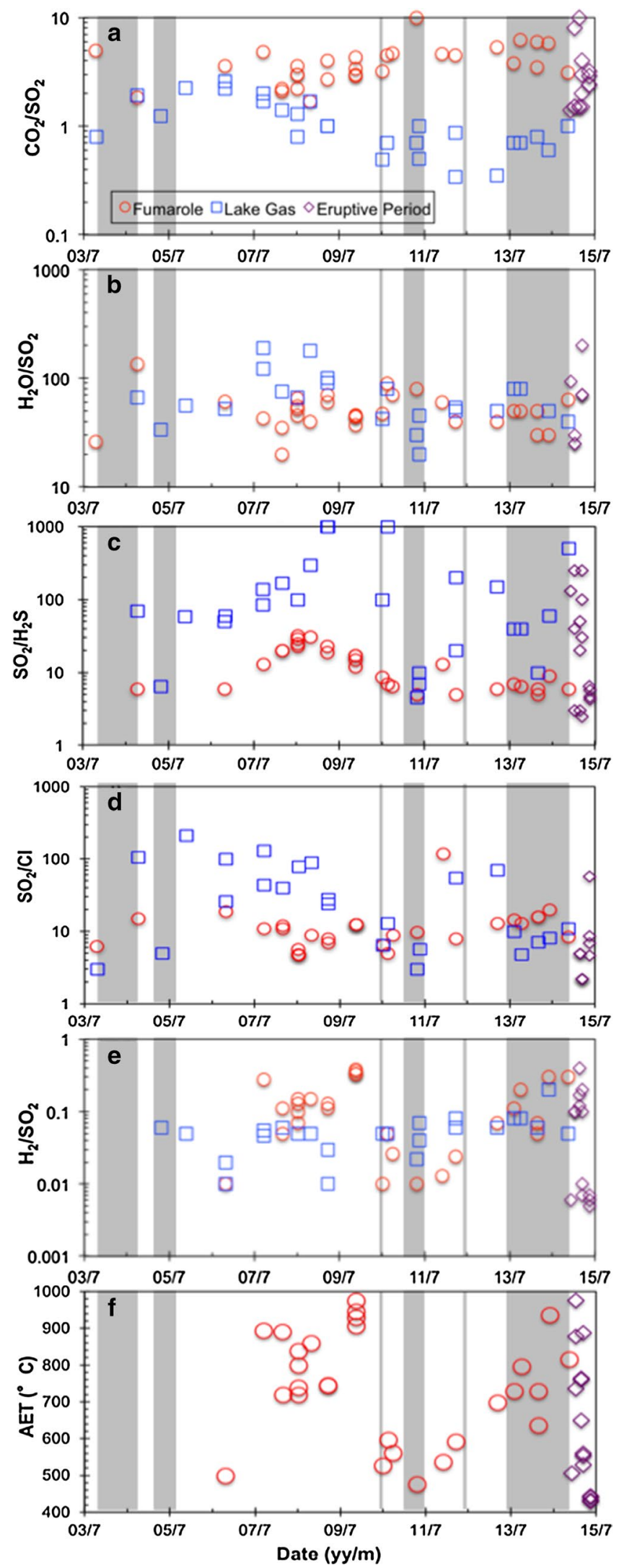


$$
\mathrm{H}_{2} \mathrm{~S}+2 \mathrm{H}_{2} \mathrm{O}=3 \mathrm{H}_{2}+\mathrm{SO}_{2} \text {. }
$$

Apparent equilibrium temperatures (AET; Matsuo 1960; Ohba et al. 1994; Shinohara et al. 2011) can be calculated for reaction (1) by the following equation (Table 1; Fig. 3f):

$$
K_{(1)}(T)=\frac{f_{\mathrm{SO}_{2}} \times f_{\mathrm{H}_{2}}^{3}}{f_{\mathrm{H}_{2} \mathrm{~S}} \times f_{\mathrm{H}_{2} \mathrm{O}}^{2}} \approx \frac{X_{\mathrm{SO}_{2}} \times X_{\mathrm{H}_{2}}^{3}}{X_{\mathrm{H}_{2} \mathrm{~S}} \times X_{\mathrm{H}_{2} \mathrm{O}}^{3}} \times P_{\mathrm{t}},
$$

where $K$ is the equilibrium constant, $f$ is the fugacity, $X$ is the mole fraction, and $P_{\mathrm{t}}$ is the total pressure. Equation (2) can be simplified to the second equations by assuming that fugacity coefficient ratios are unity and water fugacity is equal to total pressure. AETs of the fumarolic gases under an atmospheric pressure condition are calculated to range from 400 to $1000{ }^{\circ} \mathrm{C}$ (Table 1 , Fig. 3f). AETs for reaction (1) commonly agree with the measured temperature at high-temperature fumaroles, such as $>700{ }^{\circ} \mathrm{C}$ (Ohba et al. 1994; Shinohara et al. 2002). The high estimated AETs are a good proxy of fumarolic temperature and the high estimated temperatures suggest that the fumarolic gas is a direct discharge of a magmatic gas (Shinohara et al. 2015b). The AET was not calculated for the lake gases, since the $\mathrm{SO}_{2} / \mathrm{H}_{2} \mathrm{~S}$ ratios of the lake gases are largely changed by the sulfur forming reaction in the lake water.

\section{Eruptive period}

On January 12, February 25 and March 17, 2015, the measured plume compositions are quite variable during each observation. The large scatter is likely due to temporal variation of the source gas composition or of contribution from different sources. In order to quantify the temporal variation, the gas concentration ratios are obtained by comparing peak concentration of each species at the time of major $\mathrm{SO}_{2}$ concentration peak (Additional file 2: Tables S1-S3). Variation of the gas concentration ratios at the peaks are shown in Figs. 4, 5 and 6, for January 12, February 25, and 17 March, 2015, respectively. Waveforms of the infrasonic for these 3 days observed at the crater rim are shown in Fig. 7, in which occurrences of explosions with peak amplitude $>50 \mathrm{~Pa}$ are indicated by red circles. On January 12, 2015, an intensive ash emission continued during the measurement (Fig. 1c). The ash emission was accompanied by frequent explosions, and the infrasonic amplitude was continuously large (Fig. 7a). The $\mathrm{CO}_{2} / \mathrm{SO}_{2}$ and $\mathrm{SO}_{2} / \mathrm{H}_{2} \mathrm{~S}$ ratios have large ranges from 1 to 8 and from 3 to 300, respectively (Fig. 4a, d). During the early measurement by $10: 20$, the $\mathrm{CO}_{2} / \mathrm{SO}_{2}$ ratios are split into two values of two and eight. Then the ratio shows gradual decrease from eight to two after 10:55 (Fig. 4a). The $\mathrm{SO}_{2} / \mathrm{H}_{2} \mathrm{~S}$ ratios show a similar variation; two values of about five and $>15$ are observed before 10:20, and the ratios increased from about five to 100 after 10:55 (Fig. 4b). The $\mathrm{H}_{2} \mathrm{O} / \mathrm{SO}_{2}$ and $\mathrm{H}_{2} / \mathrm{SO}_{2}$ ratios are $30 \pm 13$ and $0.12 \pm 0.03$, respectively, and do not show clear temporal variation (Fig. 4c, d). The composition variation does not seem to correlate with the occurrence of explosions.

On February 25, 2015, a moderate ash emission continued during the measurement conducted at $1 \mathrm{~km}$ northeast from the crater (site 8 in Fig. 1b). Because of the distance from the crater, the plume was diluted with the air with the maximum $\mathrm{SO}_{2}$ concentration of $5.8 \mathrm{ppm}$, and a smaller number of peaks were quantified with lower quality than in January (Additional file 2: Table S2). The amplitude of infrasonic waves was relatively small until 13:05, then increased later with explosions with every 5-10 min (Fig. 7b). However, there were no changes in the appearance of the ash emission as the surficial phenomenon. The estimated ratios show a large scatter and do not show clear temporal variation (Fig. 5). The compositions obtained for peaks with relatively high concentration $\left(>4 \mathrm{ppm} \mathrm{SO}_{2}\right)$ are plotted in the same range of the ratios in January.

On March 17, 2015, an ash eruption continued during the measurement. Intensity of the ash eruption was moderate at the beginning of the measurement, and became very weak after 12:00. Fallouts of hollow salt shells were observed at the end of the measurement after 13:00 (Shinohara et al. 2018). However, no clear change in the intensity of infrasonic waves was identified regardless of the change in the ash eruption intensity (Fig. 7). The $\mathrm{CO}_{2} / \mathrm{SO}_{2}$ ratios show a scatter between 0.6 and 4 (Fig. 6a). The $\mathrm{SO}_{2} / \mathrm{H}_{2} \mathrm{~S}$ ratios varied in a large range from 2 to 400. All peaks with high $\mathrm{SO}_{2}$ concentrations (>10 ppm) have large $\mathrm{SO}_{2} / \mathrm{H}_{2} \mathrm{~S}$ ratios (>10), and majority of the low concentration peaks $(<10 \mathrm{ppm})$ have smaller ratios of less than 20 (Fig. 6b). The $\mathrm{H}_{2} \mathrm{O} / \mathrm{SO}_{2}$ ratio scatters between 30 and 400, and the ratios of the high $\mathrm{SO}_{2}$ concentration peaks ( $>10 \mathrm{ppm}$ ) have a constant value with an average of $70 \pm 23$ (Fig. 6c). The $\mathrm{H}_{2} / \mathrm{SO}_{2}$ ratios show a larger variation between 0.004 and 0.2 (Fig. 6d).

On May 19 and 20, 2015, the measurements were conducted at four different times and locations and the plume compositions are stable during each measurement (Table 1). On May 19, 2015, the plume without ashes was measured. Based on visual observation during the measurement, the plume was largely derived from the fumaroles at the southern wall with minor contribution from the main vent (Fig. 1f). On May 20, 2015, a moderate ash eruption occurred in the middle of the measurement, when the composition B on May 20, 2015, was measured (Table 1). The plume was a mixture of the main vent gas and the fumarolic gases, whose contribution are quite 

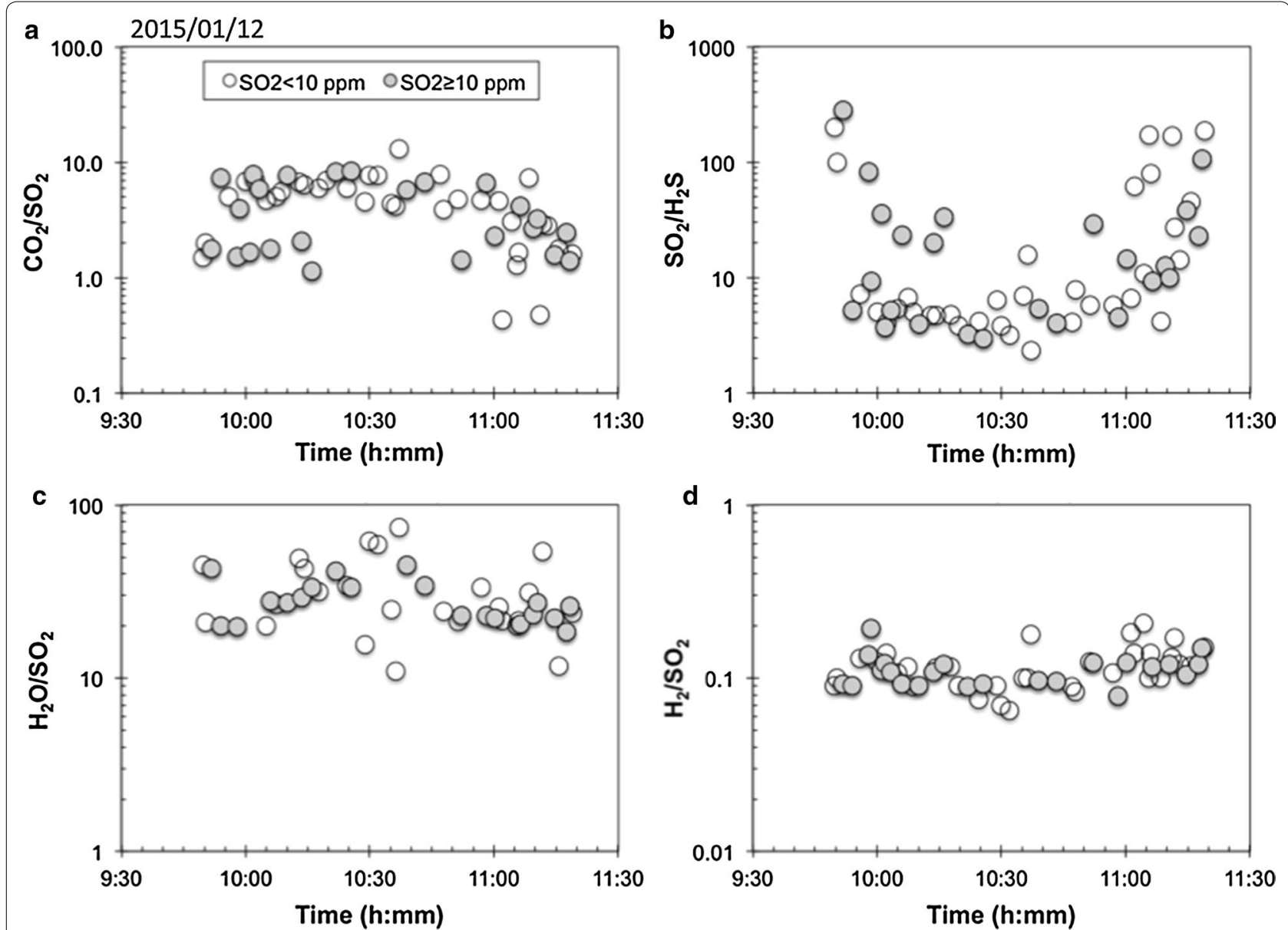

Fig. 4 A short-term variation of gas concentration molar ratios on 12 January 2015 . a $\mathrm{CO}_{2} / \mathrm{SO}_{2}$ molar ratio, $\mathbf{b} \mathrm{H}_{2} \mathrm{O} / \mathrm{SO}_{2}$ molar ratio, c $\mathrm{SO}_{2} / \mathrm{H}_{2} \mathrm{~S}$ molar ratio, and $\mathbf{d ~} \mathrm{H}_{2} / \mathrm{SO}_{2}$ molar ratio. Grey circles show ratios obtained for high concentration peaks of $\mathrm{SO}_{2} \geq 10 \mathrm{ppm}$, and white circles are ratios of low concentration peaks of $\mathrm{SO}_{2}<10 \mathrm{ppm}$

variable with time. The four compositions are similar but have a variation slightly larger than the typical errors, up to twice of the errors, except for the large $\mathrm{SO}_{2} / \mathrm{Cl}$ ratio measured on 19 May. This variation is similar to that obtained by the sequential measurement during the quiet period, such as on November 19, 2009. The composition obtained during the ash eruption (B on May 20, 2015, in Table 1) has larger $\mathrm{CO}_{2} / \mathrm{SO}_{2}$ and $\mathrm{H}_{2} / \mathrm{SO}_{2}$ ratios than other compositions ( $\mathrm{A}$ and $\mathrm{C}$ ) obtained in the same day, but the $\mathrm{CO}_{2} / \mathrm{SO}_{2}$ ratio is similar to that obtained on May 19,2015 , for the plume mainly derived from the fumarolic gas without eruption. The composition variation does not simply correlate with the sources (the main vent or the fumaroles) nor occurrence of the ash eruption.

\section{Correlation among the ratios}

A large scattering of the gas composition was observed during the eruptive period (Figs. 4, 5, 6), but the variation does not show a systematic correlation with surface manifestations, such as intensive explosions recognized in the records of the infrasonic waves. Among the variations, systematic correlations are observed between the $\mathrm{CO}_{2} / \mathrm{SO}_{2}$ and $\mathrm{SO}_{2} / \mathrm{H}_{2} \mathrm{~S}$ ratios, in particular of the results on January 12, 2015 (Fig. 8a). Logarithm of the $\mathrm{CO}_{2} / \mathrm{SO}_{2}$ ratio linearly decreases from 8 to 1.5 with increase in logarithm of the $\mathrm{SO}_{2} / \mathrm{H}_{2} \mathrm{~S}$ ratio from 3 to 30 , and the $\mathrm{CO}_{2} / \mathrm{SO}_{2}$ is a constant at $1.6 \pm 0.24$ in the $\mathrm{SO}_{2} / \mathrm{H}_{2} \mathrm{~S}$ ratio range from 30 to 300 . The $\mathrm{H}_{2} \mathrm{O} / \mathrm{SO}_{2}$ and $\mathrm{H}_{2} / \mathrm{SO}_{2}$ ratios show a larger scatter than the $\mathrm{CO}_{2} /$ $\mathrm{SO}_{2}$ and are almost constant at $30 \pm 8$ and $0.11 \pm 0.03$, respectively (Fig. 8 b, c). Based on the correlation, we assume the following three representative compositions to interpret the observed variation; the $\mathrm{CO}_{2} / \mathrm{SO}_{2}$ and $\mathrm{SO}_{2} / \mathrm{H}_{2} \mathrm{~S}$ ratios are 8 and 3.0 for composition A, 1.6 and 30 for $\mathrm{B}$ and 1.6 and 300 for $\mathrm{C}$ (Table 1). All compositions have the same $\mathrm{H}_{2} \mathrm{O} / \mathrm{SO}_{2}$ and $\mathrm{H}_{2} / \mathrm{SO}_{2}$ ratios of 30 and 0.11 , respectively. The AETs under one atmosphere condition are calculated for the compositions A, B and 

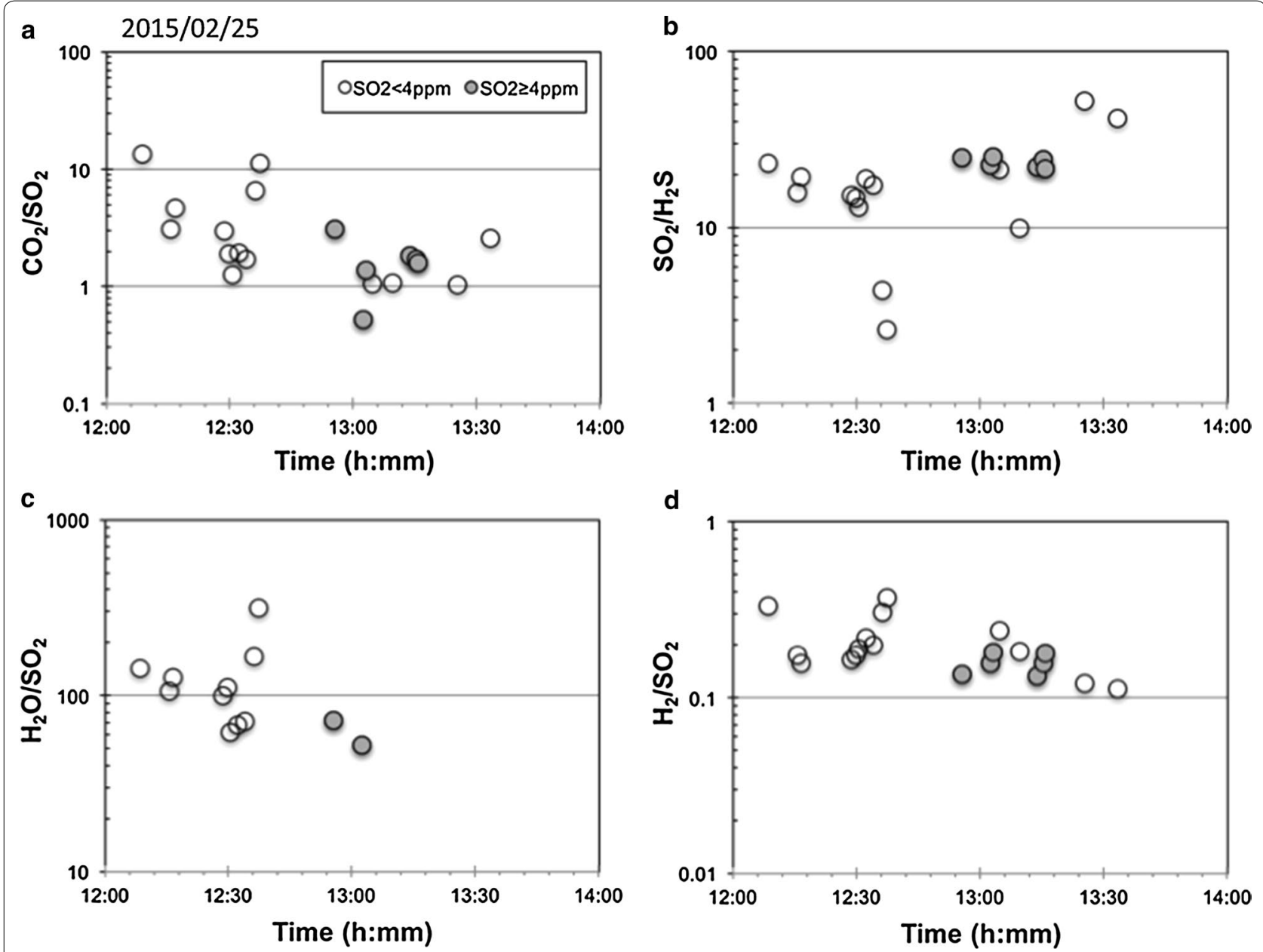

Fig. 5 A short-term variation of gas concentration molar ratios on 25 February 2015 . a $\mathrm{CO}_{2} / \mathrm{SO}_{2}$ molar ratio, b $\mathrm{H}_{2} \mathrm{O} / \mathrm{SO}_{2}$ molar ratio, c $\mathrm{SO}_{2} / \mathrm{H}_{2} \mathrm{~S}$ molar ratio, and $\mathbf{d} \mathrm{H}_{2} / \mathrm{SO}_{2}$ molar ratio. Grey circles show ratios obtained for high concentration peaks of $\mathrm{SO}_{2} \geq 4 \mathrm{ppm}$, and white circles are ratios of low concentration peaks of $\mathrm{SO}_{2}>4 \mathrm{ppm}$

$\mathrm{C}$ as $770{ }^{\circ} \mathrm{C}, 870{ }^{\circ} \mathrm{C}$ and $990^{\circ} \mathrm{C}$, respectively (Table 1 ). The highest estimated temperature of $990{ }^{\circ} \mathrm{C}$ agrees with the petrological estimate of the magma temperature, ranging from 1000 to $1100{ }^{\circ} \mathrm{C}$ (Saito et al. 2017).

On February 25, 2015, the high $\mathrm{SO}_{2}$ concentration peaks $\left(>4 \mathrm{ppm}\right.$ ) have a similar composition of $\mathrm{CO}_{2} /$ $\mathrm{SO}_{2}=1.7 \pm 0.8, \quad \mathrm{SO}_{2} / \mathrm{H}_{2} \mathrm{~S}=24 \pm 1.5, \quad \mathrm{H}_{2} \mathrm{O} / \mathrm{SO}_{2}=63 \pm 14$ and $\mathrm{H}_{2} / \mathrm{SO}_{2}=0.16 \pm 0.02$ (composition B'; Fig. 9; Table 1). This composition is similar to the $\mathrm{B}$ composition on January 12, 2015, except for the $\mathrm{H}_{2} \mathrm{O} / \mathrm{SO}_{2}$ ratio. Two low $\mathrm{SO}_{2}$ peaks of small $\mathrm{SO}_{2} / \mathrm{H}_{2} \mathrm{~S}$ ratios around 3 have the $\mathrm{CO}_{2} /$ $\mathrm{SO}_{2}$ ratios around 8, that agree with the $\mathrm{A}$ composition in January, but have the larger $\mathrm{H}_{2} \mathrm{O} / \mathrm{SO}_{2}$ and $\mathrm{H}_{2} / \mathrm{SO}_{2}$ ratios of 200 and 0.3 , respectively, than the $\mathrm{A}$ composition (composition $\mathrm{A}^{\prime}$ ). The composition A', however, has a large uncertainty due to the low $\mathrm{SO}_{2}$ concentration. The AETs under one atmosphere condition for the compositions $\mathrm{B}^{\prime}$ is calculated as $790^{\circ} \mathrm{C}$ (Table 1 ).
On March 17, 2015, the data show a larger scatter on the $\mathrm{CO}_{2} / \mathrm{SO}_{2}-\mathrm{SO}_{2} / \mathrm{H}_{2} \mathrm{~S}$ diagram but the data distribution largely overlaps with that on January 12, 2015 (Fig. 10a). The high $\mathrm{SO}_{2}$ concentration peaks $(>10 \mathrm{ppm})$ have large $\mathrm{SO}_{2} / \mathrm{H}_{2} \mathrm{~S}$ ratios $(>10)$. The $\mathrm{CO}_{2} / \mathrm{SO}_{2}$ ratio of these peaks scatters between 0.6 and 4 , and has an average value of $1.6 \pm 0.8$, which is similar to the composition $\mathrm{B}$ and $\mathrm{C}$ of 12 January. With decreasing $\mathrm{SO}_{2} / \mathrm{H}_{2} \mathrm{~S}$ ratio, $\mathrm{CO}_{2} / \mathrm{SO}_{2}$ ratio increases up to 4 , which is slightly smaller than 8 of the composition A on 12 January. The peaks with large $\mathrm{SO}_{2} / \mathrm{H}_{2} \mathrm{~S}$ ratios $(>30)$ have a constant $\mathrm{H}_{2} \mathrm{O} / \mathrm{SO}_{2}$ ratio at $68 \pm 20$, which is similar to the composition on 25 February. The $\mathrm{H}_{2} \mathrm{O} / \mathrm{SO}_{2}$ ratio increases up to 200 with decreasing $\mathrm{SO}_{2} / \mathrm{H}_{2} \mathrm{~S}$ ratio down to 3 . The $\mathrm{H}_{2} / \mathrm{SO}_{2}$ ratio increases from 0.005 to 0.1 with decreasing $\mathrm{SO}_{2} / \mathrm{H}_{2} \mathrm{~S}$ ratio from 300 to 30. Based on these variation, representative composition of A", B" and C" are estimated (Table 1), however, the composition $\mathrm{A}^{\prime \prime}$ have a large uncertainty due to the 

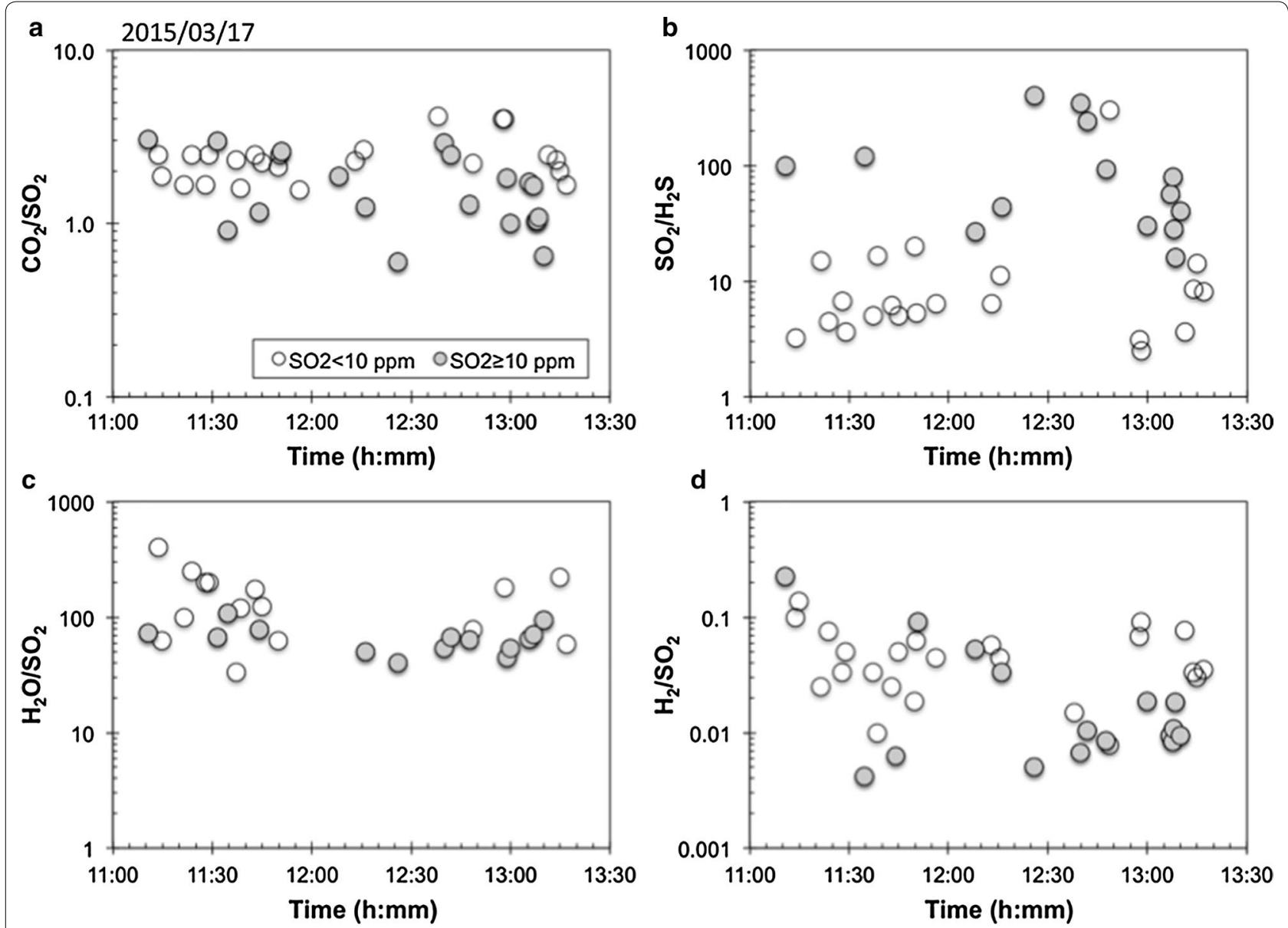

Fig. 6 A short-term variation of gas concentration molar ratios on $17 \mathrm{March} 2015 . \mathbf{a ~} \mathrm{CO}_{2} / \mathrm{SO}_{2}$ molar ratio, $\mathbf{b ~} \mathrm{H}_{2} \mathrm{O} / \mathrm{SO}_{2}$ molar ratio, c $\mathrm{SO}_{2} / \mathrm{H}_{2} \mathrm{~S}$ molar ratio, and $\mathbf{d} \mathrm{H}_{2} / \mathrm{SO}_{2}$ molar ratio. Grey circles show ratios obtained for high concentration peaks of $\mathrm{SO}_{2} \geq 10 \mathrm{ppm}$, and white circles are ratios of low concentration peaks of $\mathrm{SO}_{2}<10 \mathrm{ppm}$

low $\mathrm{SO}_{2}$ concentration. The AETs under one atmosphere condition of the compositions A", B" and C" are $570{ }^{\circ} \mathrm{C}$, $530^{\circ} \mathrm{C}$ and $560{ }^{\circ} \mathrm{C}$, respectively (Table 1 ).

The $\mathrm{CO}_{2} / \mathrm{SO}_{2}$ and $\mathrm{SO}_{2} / \mathrm{H}_{2} \mathrm{~S}$ ratios of May 2015 are $2.9 \pm 0.6$ and $5.1 \pm 1.3$, respectively, and are similar to composition A" of March 17, 2015. The $\mathrm{H}_{2} / \mathrm{SO}_{2}$ ratio of March is $0.008 \pm 0.003$, which is smaller than the composition A" but similar to the $\mathrm{H}_{2} / \mathrm{SO}_{2}$ ratios with large $\mathrm{SO}_{2} /$ $\mathrm{H}_{2} \mathrm{~S}$ ratios such as compositions B" and C". The AET is calculated as about $440^{\circ} \mathrm{C}$ by assuming one atmosphere and $\mathrm{H}_{2} \mathrm{O} / \mathrm{SO}_{2}=100$ (Table 1).

\section{Discussion}

\section{Eruptive period}

\section{Composition variation on January 12, 2015}

The $\mathrm{CO}_{2} / \mathrm{SO}_{2}$ and $\mathrm{SO}_{2} / \mathrm{H}_{2} \mathrm{~S}$ ratios on January 12, 2015, show a systematic correlation; the data align on two straight lines among three representative compositions A, B and C (Fig. 8a). The composition variation can be caused either by mixing of gases from three sources or by temporal variation of gas composition. Even during the eruptive period, there are two degassing sources: the erupting vent and the fumarolic area on the southern crater wall (Fig. 1). However, on January 12, 2015, the crater was filled with the ash laden plume discharged by intensive ash eruption and the erupting vent seems to be a far dominant source of the plume. The rapid and large composition variation is likely reflecting the variation of degassing condition at the erupting vent.

Variation of $\mathrm{CO}_{2} / \mathrm{SO}_{2}$ ratio of magmatic gases is observed at various volcanoes and has often been attributed to changes in gas-magma equilibrium pressure. Because of the low solubility, $\mathrm{CO}_{2}$ starts effective exsolution at pressure higher than $\mathrm{S}$, resulting in a larger $\mathrm{CO}_{2} / \mathrm{S}$ ratio in gases exsolved at a higher pressure (Burgisser et al. 2015; Edmonds 2008). Rapid variation of $\mathrm{CO}_{2} / \mathrm{SO}_{2}$ ratio during Strombolian or lava fountaining eruptions at Stromboli and Etna volcanoes are interpreted to be 

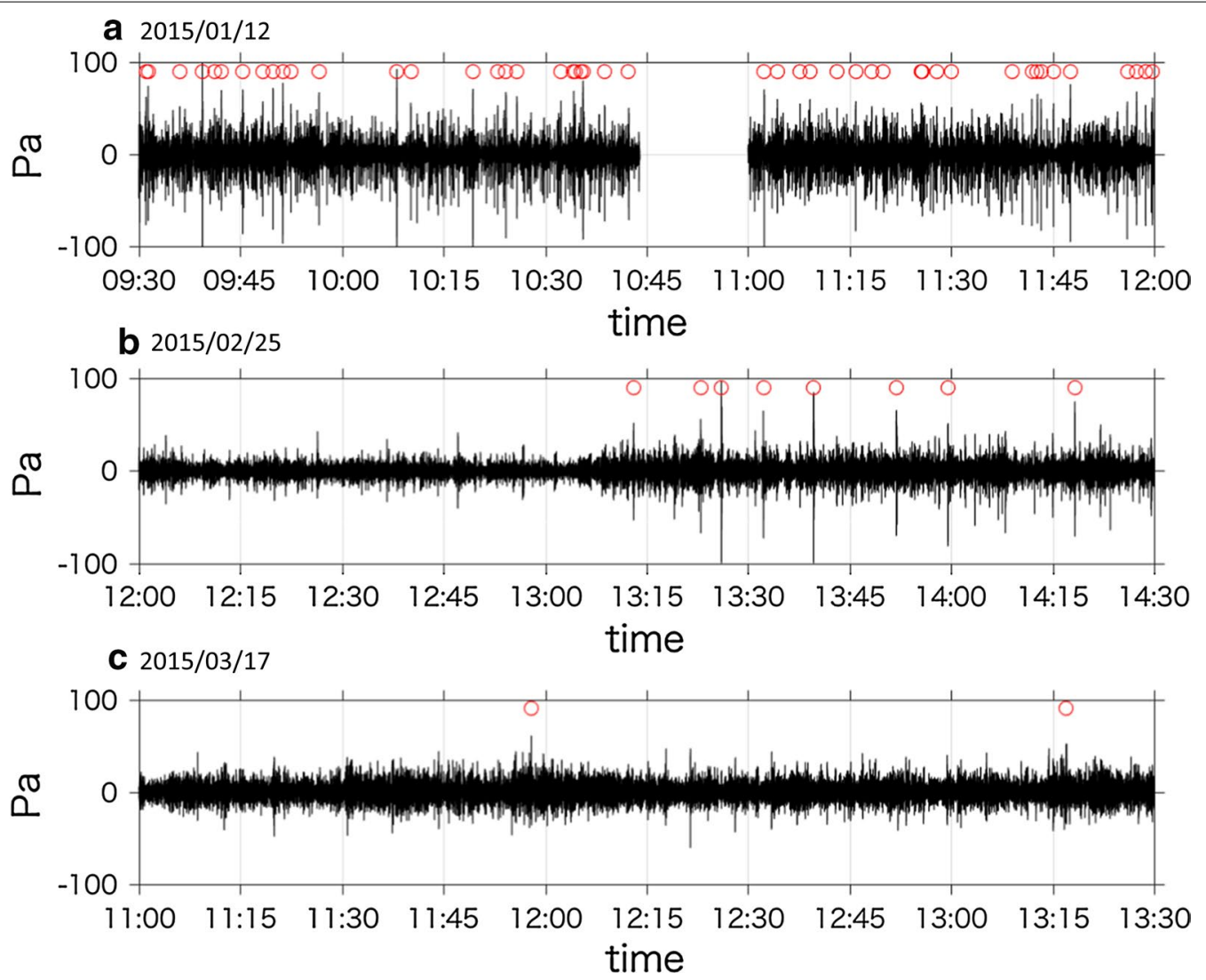

Fig. 7 Infrasonic waveforms observed at the location 4 on Fig. 1. Red circles indicate explosions with peak pressures of $>50$ Pa. Data-gap of 15 min was due to works at the station

due to variation of the pressure from which the gases are derived (Allard 2010; Burton et al. 2007; La Spine et al. 2015). Increases of $\mathrm{CO}_{2} / \mathrm{SO}_{2}$ ratios are observed prior to paroxysm eruptions at Stromboli and Villarrica volcanoes and are attributed to supply of $\mathrm{CO}_{2}$-rich bubbled formed at a deep source (Aiuppa et al. 2009, 2017). A solubility modeling revealed that the $\mathrm{CO}_{2} / \mathrm{S}_{\mathrm{t}}$ ratio range from 0.65 to 9.1 measured at Villarrica volcano corresponds to variation of the equilibration pressures ranging from 0.1 to 20-35 MPa (Aiuppa et al. 2017). The $\mathrm{CO}_{2} / \mathrm{SO}_{2}$ ratio variation from 1.6 to 8 observed on January 12, 2015, at the Nakadake crater can be caused by a similar variation in the equilibrium pressure.

The variation of the $\mathrm{CO}_{2} / \mathrm{SO}_{2}$ ratio is associated with a large variation of the $\mathrm{SO}_{2} / \mathrm{H}_{2} \mathrm{~S}$ ratio from 3 to 300 (Fig. 8). A large $\mathrm{SO}_{2} / \mathrm{H}_{2} \mathrm{~S}$ ratio is a common feature of high-temperature fumarolic gases and a small ratio is that of low-temperature gases. These features are commonly considered as a result of temperature dependence of sulfur redox reaction equilibrium (Giggenbach 1987; Symonds et al. 1994). Under an oxygen fugacity controlled by a solid-state buffer, such as QFM, temperature dependence of the $\mathrm{H}_{2} / \mathrm{H}_{2} \mathrm{O}$ ratio in the gas phase is small (Giggenbach 1987) and the large temperature dependence of the equilibrium constant of the reaction (1) results in a large $\mathrm{SO}_{2} / \mathrm{H}_{2} \mathrm{~S}$ variation with temperature (Fig. 10 in de Moor et al. 2016). The decrease in $\mathrm{SO}_{2} /$ $\mathrm{H}_{2} \mathrm{~S}$ ratios from 300 to 3 can be caused by temperature decrease in an equilibrium magma degassing from 1000 to $770{ }^{\circ} \mathrm{C}$ under an oxygen fugacity buffer of $\triangle \mathrm{QFM}+1.3$. The estimated temperature range agrees with the range of the apparent equilibrium temperatures (Table 1), and the highest temperature is a reasonable temperature of the erupting basaltic andesite magma.

The estimated temperature of $770{ }^{\circ} \mathrm{C}$ seems to be too low as a temperature of the erupting magma (Saito et al. 2017). Heterogeneous cooling of a magma can be caused by mixing with the air or hydrothermal solution, or adiabatic expansion of bubbles. The air or hydrothermal solution contains atmospheric oxygen and the mixing results in oxidation and cannot cause the observed composition variation. An adiabatic expansion of rapidly ascending bubbles can cause a significant cooling. Burgisser et al. (2012) demonstrated that an isentropic expansion of bubbles from 0.5 to $0.065 \mathrm{MPa}$ can cause a cooling of $350{ }^{\circ} \mathrm{C}$. Many explosions occurred during the 

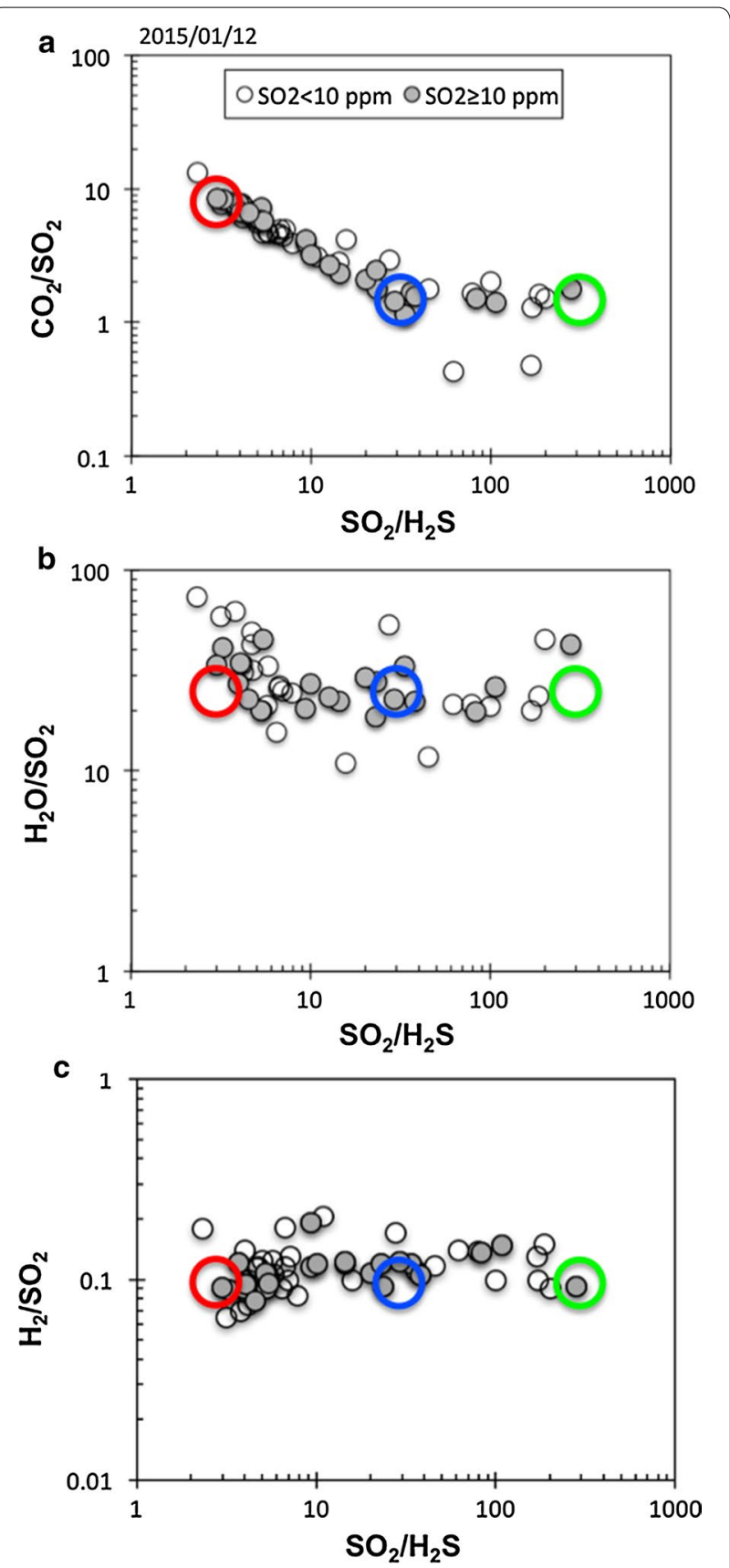

Fig. 8 Correlation of gas concentration molar ratios on 12 January 2015. a correlation of $\mathrm{CO}_{2} / \mathrm{SO}_{2}$ molar ratio with $\mathrm{SO}_{2} / \mathrm{H}_{2} \mathrm{~S}$ molar ratio, b correlation of $\mathrm{H}_{2} \mathrm{O} / \mathrm{SO}_{2}$ molar ratio with $\mathrm{SO}_{2} / \mathrm{H}_{2}$ molar ratio, and c correlation of $\mathrm{H}_{2} / \mathrm{SO}_{2}$ molar ratio with $\mathrm{SO}_{2} / \mathrm{H}_{2} \mathrm{~S}$ molar ratio. Grey circles show ratios obtained for high concentration peaks of $\mathrm{SO}_{2} \geq 10$ ppm, and white circles are ratios of low concentration peaks of $\mathrm{SO}_{2}<10 \mathrm{ppm}$. Red, blue and green circles indicate the compositions $A, B$ and $C$, respectively

measurement (Fig. 7), and the explosion can be caused by the rapidly ascending bubbles. The adiabatic bubble expansion occurs with an absence of thermal interaction with the surrounding magma. Under such a condition, oxygen fugacity of the gas cannot be controlled by the magma, as the chemical exchange is slower than the thermal exchange. The $\mathrm{SO}_{2} / \mathrm{H}_{2} \mathrm{~S}$ variation is less likely caused by the temperature variation under a control of an oxygen fugacity buffer. Furthermore, the large $\mathrm{CO}_{2} / \mathrm{SO}_{2}$ variation is less likely caused by the temperature variation. Few studies on magma degassing focused on temperature dependence but mainly on pressure, magma composition or redox dependences (Burgisser et al. 2015; Moretti et al. 2003; Witham et al. 2012). In general, temperature dependences of volatile solubility in a silicate melt are rather minor than their pressure and composition dependence (e.g., Holloway and Blank 1994).

A closed-system cooling of a gas phase also decreases $\mathrm{SO}_{2} / \mathrm{H}_{2} \mathrm{~S}$ ratio by temperature dependence of reaction (1). The amount of $\mathrm{H}_{2} \mathrm{~S}$ which can be produced by the equilibrium shift is limited by the amount of $\mathrm{H}_{2}$ in the original gases. Reaction (1) consumes three moles of $\mathrm{H}_{2}$ to form one mole of $\mathrm{H}_{2} \mathrm{~S}$. The closed-system cooling of the gases with $\mathrm{H}_{2} / \mathrm{SO}_{2}$ of 0.1 cannot decrease the $\mathrm{SO}_{2} /$ $\mathrm{H}_{2} \mathrm{~S}$ ratio from 300 to 3 . Consumption of all $\mathrm{H}_{2}(0.1 \mathrm{~mol})$ in an original gas with $1 \mathrm{~mol}$ of $\mathrm{SO}_{2}$ produces $0.033 \mathrm{~mol}$ of $\mathrm{H}_{2} \mathrm{~S}$, resulting in the $\mathrm{SO}_{2} / \mathrm{H}_{2} \mathrm{~S}$ ratio decrease from 300 to 28 and the $\mathrm{H}_{2} / \mathrm{SO}_{2}$ decrease from 0.1 to zero. The decrease in $\mathrm{SO}_{2} / \mathrm{H}_{2} \mathrm{~S}$ by reaction (1) should be associated with the $\mathrm{H}_{2} / \mathrm{SO}_{2}$ decrease. The constant $\mathrm{H}_{2} / \mathrm{SO}_{2}$ ratio indicates an absence of the simple closed-system cooling.

Variation of the gas-magma equilibrium pressure can cause a variation of the $\mathrm{SO}_{2} / \mathrm{H}_{2} \mathrm{~S}$ ratio. Under a condition of the gas-magma equilibrium, temperature and oxygen fugacity is likely constant, where the $\mathrm{SO}_{2} / \mathrm{H}_{2} \mathrm{~S}$ ratio is proportional to a reciprocal of total pressure (Eq. 2). A pressure variation from 0.1 to $20-35 \mathrm{MPa}$ is suggested to cause the $\mathrm{CO}_{2} / \mathrm{SO}_{2}$ ratio variation from 1.6 to 8 . The $\mathrm{SO}_{2} /$ $\mathrm{H}_{2} \mathrm{~S}$ ratio decreases from 300 to 3 can be caused by a two orders of magnitude increase in the equilibrium pressure, e.g., from 0.2 to $20 \mathrm{MPa}$. The $\mathrm{CO}_{2} / \mathrm{SO}_{2}$ ratio shows the negative correlation with the $\mathrm{SO}_{2} / \mathrm{H}_{2} \mathrm{~S}$ ratio in $\mathrm{SO}_{2} /$ $\mathrm{H}_{2} \mathrm{~S}$ ratio range from 3 to 30 , but the $\mathrm{CO}_{2} / \mathrm{SO}_{2}$ ratio is almost constant in the larger $\mathrm{SO}_{2} / \mathrm{H}_{2} \mathrm{~S}$ ratio range from 30 to 300 (Fig. 8). The different correlation can be due to different pressure dependences of the $\mathrm{CO}_{2} / \mathrm{SO}_{2}$ and $\mathrm{SO}_{2} /$ $\mathrm{H}_{2} \mathrm{~S}$ ratios. The linear pressure dependence on the $\mathrm{SO}_{2} /$ $\mathrm{H}_{2} \mathrm{~S}$ ratio (Eq. 2) implies that the $\mathrm{SO}_{2} / \mathrm{H}_{2} \mathrm{~S}$ ratios of 3, 30 and 300 of the compositions $\mathrm{A}, \mathrm{B}$ and $\mathrm{C}$ can be created at the equilibrium pressures of $0.2,2.0$ and $20 \mathrm{MPa}$, respectively. In contrast, a logarithm of the $\mathrm{CO}_{2} / \mathrm{S}$ ratio is proportional to the pressure (Fig. 7 in Aiuppa et al. 2017). The pressure decrease from 2.0 to $0.2 \mathrm{MPa}$ causes only a small decrease in the $\mathrm{CO}_{2} / \mathrm{SO}_{2}$ ratio from 1.7 to 1.5 . The small difference cannot be quantified by the present method, and the $\mathrm{CO}_{2} / \mathrm{SO}_{2}$ ratios are judged as a constant 

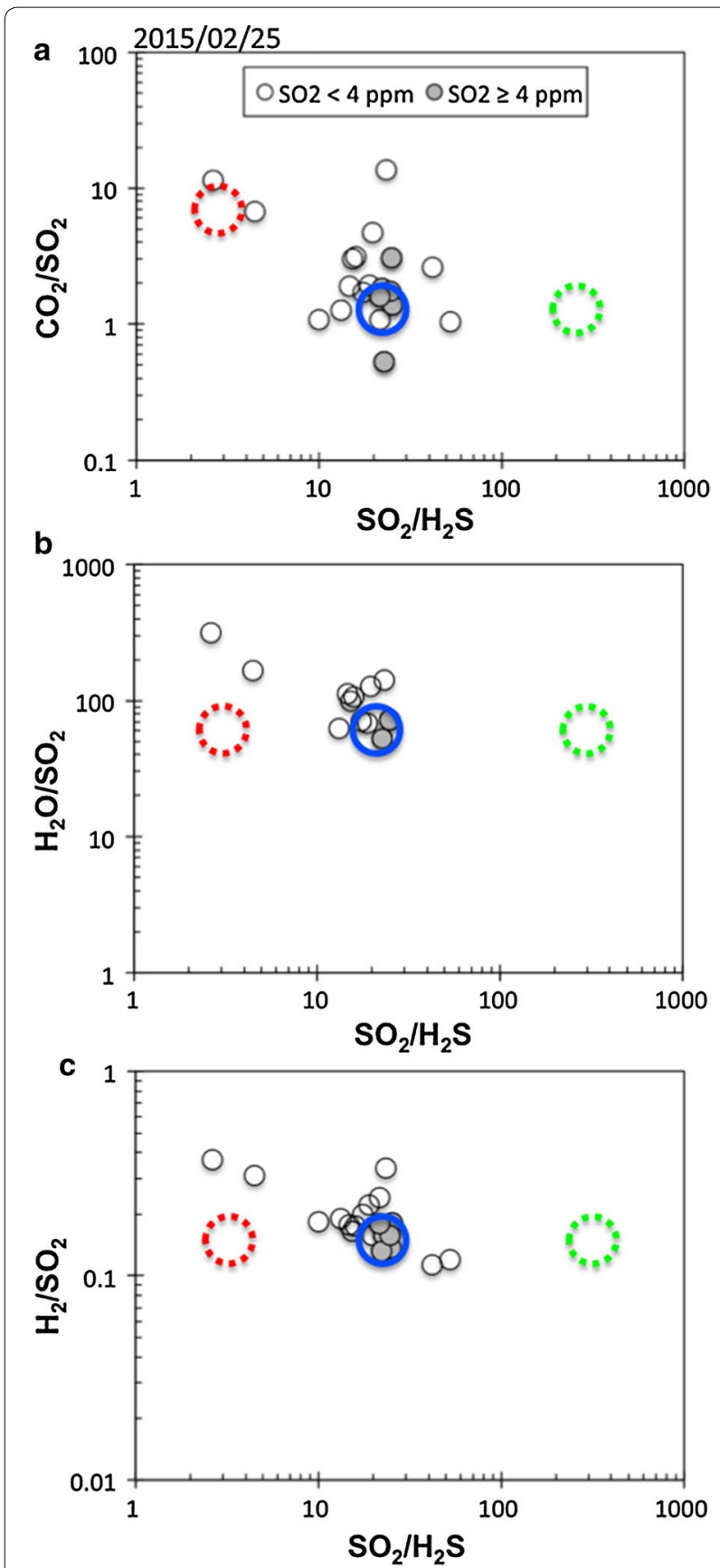

Fig. 9 Correlation of gas concentration molar ratios on 25 February 2015. a correlation of $\mathrm{CO}_{2} / \mathrm{SO}_{2}$ molar ratio with $\mathrm{SO}_{2} / \mathrm{H}_{2} \mathrm{~S}$ molar ratio, b correlation of $\mathrm{H}_{2} \mathrm{O} / \mathrm{SO}_{2}$ molar ratio with $\mathrm{SO}_{2} / \mathrm{H}_{2} \mathrm{~S}$ molar ratio, and c correlation of $\mathrm{H}_{2} / \mathrm{SO}_{2}$ molar ratio with $\mathrm{SO}_{2} / \mathrm{H}_{2} \mathrm{~S}$ molar ratio. Grey circles show ratios obtained for high concentration peaks of $\mathrm{SO}_{2} \geq 4$ $\mathrm{ppm}$, and white circles are ratios of low concentration peaks of $\mathrm{SO}_{2}>4 \mathrm{ppm}$. Blue circle indicates the composition $\mathrm{B}^{\prime}$, and red and green dotted circles indicate the compositions $A$ and $B$, respectively under these conditions. At these pressures, the AETs of the compositions $\mathrm{A}, \mathrm{B}$ and $\mathrm{C}$ are calculated as a common temperature of $990^{\circ} \mathrm{C}$ for the three compositions.

Kinetics of gas reactions are faster than those of gasmagma reactions and reactions among gas species will remain in thermodynamic equilibrium during a rapid bubble ascent in magmas even under a condition causing the adiabatic cooling (Burgisser et al. 2012). By a pressure decrease, reaction (1) proceeds to the right side and the $\mathrm{SO}_{2} / \mathrm{H}_{2} \mathrm{~S}$ and $\mathrm{H}_{2} / \mathrm{H}_{2} \mathrm{O}$ ratios increase. The gases exsolved at a high pressure will change composition by the rapid ascent of bubbles and will have a composition in equilibrium under the atmospheric pressure condition at the surface. Under the atmospheric pressure $(0.1 \mathrm{MPa})$, the AETs of the compositions $\mathrm{A}, \mathrm{B}$ and $\mathrm{C}$ are $770{ }^{\circ} \mathrm{C}, 870{ }^{\circ} \mathrm{C}$ and $990^{\circ} \mathrm{C}$ (Table 1). The difference in the AETs can be due to the adiabatic cooling of the gas phase by decompression; the composition $\mathrm{A}$ gas equilibrated with the magma at $20 \mathrm{MPa}$ and $990{ }^{\circ} \mathrm{C}$ cooled to $770{ }^{\circ} \mathrm{C}$ at $0.2 \mathrm{MPa}$, and the composition $\mathrm{B}$ gas equilibrated with the magma at $2.0 \mathrm{MPa}$ and $990{ }^{\circ} \mathrm{C}$ cooled to $870{ }^{\circ} \mathrm{C}$ at $0.2 \mathrm{MPa}$. The constant $\mathrm{H}_{2} \mathrm{O} / \mathrm{SO}_{2}$ ratio of 30 may correspond to the ratio of the bulk magmatic gas discharged on January 12, 2015.

\section{Composition variation during the later eruptive period}

The $\mathrm{CO}_{2} / \mathrm{SO}_{2}$ and $\mathrm{SO}_{2} / \mathrm{H}_{2} \mathrm{~S}$ ratios of February 25 and March 17, 2015, show a larger scatter but are plotted along the correlation observed on January 12, 2015 (Figs. 8, 9, 10). The compositions B', B" and C" are similar to the composition $B$ or $C$ (Table 1; Fig. 11a), suggesting these gases are derived from similar conditions of those on 12 January. The composition A" of March 17, 2015, has a smaller $\mathrm{CO}_{2} / \mathrm{SO}_{2}$ ratio of 4 compared with that of 8 on January 12, 2015. The pressure dependence of the $\mathrm{CO}_{2} / \mathrm{S}$ ratio (Aiuppa et al. 2017) suggests that the twice smaller $\mathrm{CO}_{2} / \mathrm{SO}_{2}$ ratio can be caused by a twice lower equilibrium pressure. The lower equilibrium pressure should also cause a larger $\mathrm{SO}_{2} / \mathrm{H}_{2} \mathrm{~S}$ ratio of the gas phase, that is not the case on March 17, 2015. This discrepancy might be, at least partly, due to a larger estimation error of the $\mathrm{CO}_{2} / \mathrm{SO}_{2}$ and $\mathrm{SO}_{2} / \mathrm{H}_{2} \mathrm{~S}$ ratios of the composition $\mathrm{A}^{\prime}$ than of the composition $\mathrm{A}$, because of the low plume concentrations (Fig. 10). The $\mathrm{CO}_{2} / \mathrm{SO}_{2}$ and $\mathrm{SO}_{2} / \mathrm{H}_{2} \mathrm{~S}$ ratios in May 2015 are $2.9 \pm 0.6$ and $5.1 \pm 1.3$, respectively (Table 1; Fig. 11a). These gases have intermediate compositions of composition A" and B" on March 17, 2015, and are likely in the gas-magma equilibrium under intermediate pressures between 2 and $10 \mathrm{MPa}$.

The $\mathrm{H}_{2} / \mathrm{SO}_{2}$ ratio of the composition B' on 25 February is similar to that of the composition B on 19 January, resulting in a similar but slightly lower AET of $790{ }^{\circ} \mathrm{C}$ than that of the composition $\mathrm{B}$ (Table 1). The composition 

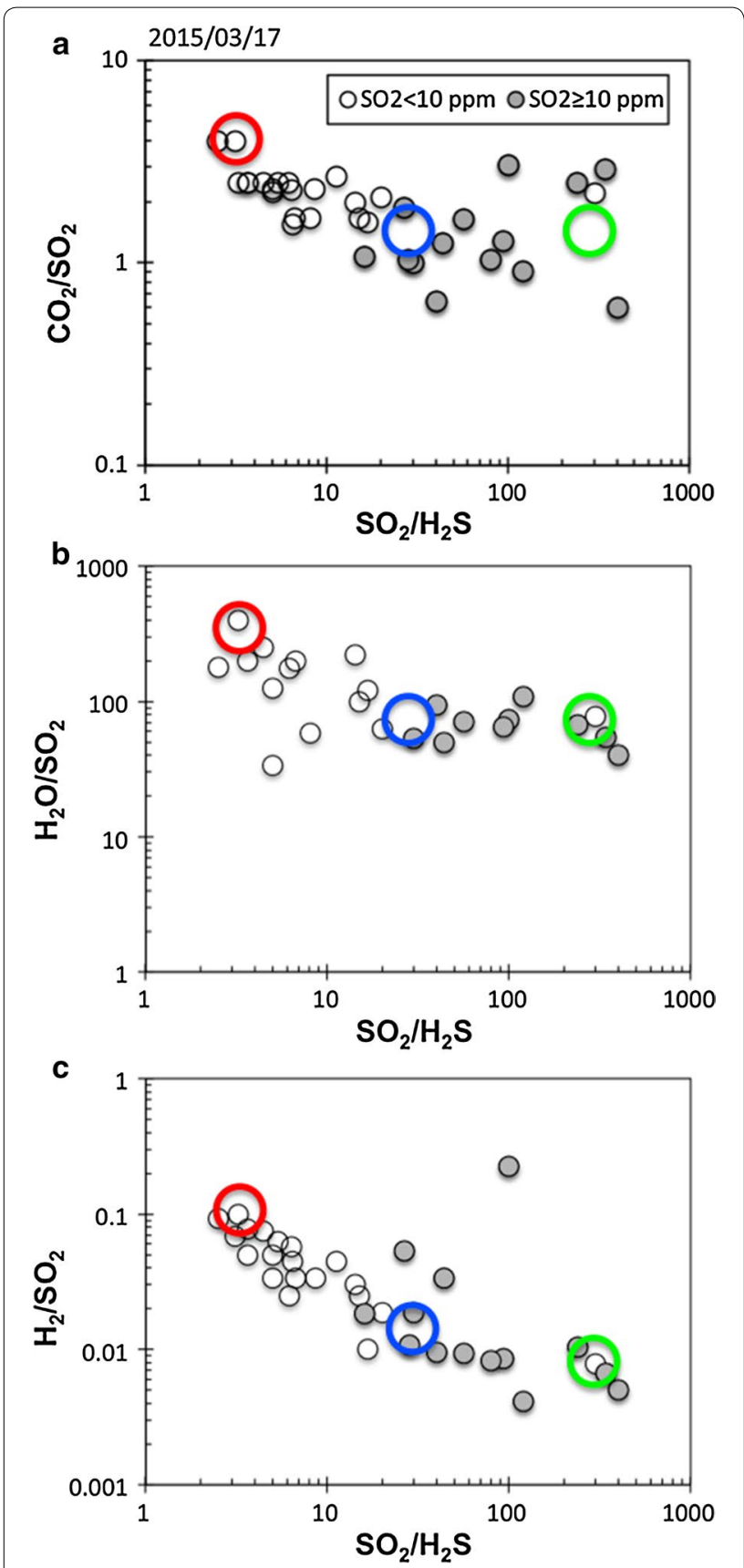

Fig. 10 Correlation of gas concentration molar ratios on 17 March 2015. a correlation of $\mathrm{CO}_{2} / \mathrm{SO}_{2}$ molar ratio with $\mathrm{SO}_{2} / \mathrm{H}_{2} \mathrm{~S}$ molar ratio, b correlation of $\mathrm{H}_{2} \mathrm{O} / \mathrm{SO}_{2}$ molar ratio with $\mathrm{SO}_{2} / \mathrm{H}_{2} \mathrm{~S}$ molar ratio, and c correlation of $\mathrm{H}_{2} / \mathrm{SO}_{2}$ molar ratio with $\mathrm{SO}_{2} / \mathrm{H}_{2} \mathrm{~S}$ molar ratio. Grey circles show ratios obtained for high concentration peaks of $\mathrm{SO}_{2} \geq 10$ ppm, and white circles are ratios of low concentration peaks of $\mathrm{SO}_{2}<10 \mathrm{ppm}$. Red, blue and green circles indicate the compositions $A^{\prime \prime}, B^{\prime \prime}$ and $C^{\prime \prime}$, respectively

B' can be explained by adiabatic cooling of the gas phase equilibrated with the magma at $2 \mathrm{MPa}$, similar to composition $\mathrm{B}$. The slightly lower AET is due to a larger $\mathrm{H}_{2} \mathrm{O}$ /
$\mathrm{SO}_{2}$ ratio of composition $\mathrm{B}$ " (60) than that of composition B (30; Fig. 11b). The larger $\mathrm{H}_{2} \mathrm{O} / \mathrm{SO}_{2}$ ratio can be due to a mixing of an external water, such as a hydrothermal solution at shallow depth surrounding the erupting vent, suggested by fallouts of salt materials (Shinohara et al. 2018). The salt fallouts were observed during the eruptive period of the Nakadake crater, and have a round hollow shell structure and compositions similar to the crater lake water. These features suggest that the salts are formed by drying droplets of a hydrothermal solution in the erupting plume, implying distribution of a hydrothermal solution near surface surrounding the erupting vent (Shinohara et al. 2018).

The $\mathrm{H}_{2} / \mathrm{SO}_{2}$ ratios of the composition B" and C" on 17 March are much smaller than those in the early stage, results in lower AETs (Table 1; Fig. 11c). The composition $\mathrm{A}^{\prime}$ has a $\mathrm{H}_{2} / \mathrm{SO}_{2}$ ratio of 0.1 , similar to those of the early stage, but has a larger $\mathrm{H}_{2} \mathrm{O} / \mathrm{SO}_{2}$ ratio of 400 , resulting in a low AET of $510{ }^{\circ} \mathrm{C}$, similar to the AETs of the compositions $\mathrm{B}$ " and C". The chemical shift of reaction (1) in a gas phase by cooling can explain the difference of the compositions $\mathrm{B}$ and $\mathrm{B}$, but not of $\mathrm{C}$ and $\mathrm{C}$." If the $\mathrm{H}_{2} / \mathrm{SO}_{2}$ ratios of compositions $\mathrm{B}$ and $\mathrm{C}$ decrease from 0.1 to $0.01, \mathrm{SO}_{2} / \mathrm{H}_{2} \mathrm{~S}$ ratios decrease from 30 to 16 , and from 300 to 30 , respectively. If the composition C" is also derived from a magma degassing at a low pressure, similar to the composition $C$, an additional oxidation process may be required for the composition C", such as a mixing with the air. The $\mathrm{H}_{2} \mathrm{O} / \mathrm{SO}_{2}$ ratios of the compositions A", B" and C" are larger than those on January 12, 2015 (Fig. 11b), and can be due to a mixing of a hydrothermal solution, as suggested for the composition B. The low AETs on March 17, 2015, can be partly due to cooling by the mixing of a hydrothermal solution. The shallow hydrothermal solution may contain oxygen derived from the air and can contribute oxidation of the gas components. Further evaluation, however, cannot be made with the present limited information.

The $\mathrm{H}_{2} / \mathrm{SO}_{2}$ ratios in May 2015 are similarly low to those of the compositions B" and C". $\mathrm{H}_{2} \mathrm{O} / \mathrm{SO}_{2}$ ratios were not quantified in May because of a larger fluctuation of the background $\mathrm{H}_{2} \mathrm{O}$ concentration in the atmosphere. By assuming the $\mathrm{H}_{2} \mathrm{O} / \mathrm{SO}_{2}=100$, AETs are calculated as $430-440{ }^{\circ} \mathrm{C}$, which are even lower than those on 17 March (Fig. 11c). The low AETs suggest further cooling of the gases by an increase in the hydrothermal contribution.

\section{Degassing process during the eruptive period}

The Nakadake is a persistently degassing volcanic cone, which discharges 200-600 t/d of $\mathrm{SO}_{2}$ even during the quiet period (Miyabuchi and Terada 2009; Shinohara et al. 2015b). The persistent degassing can be caused by 

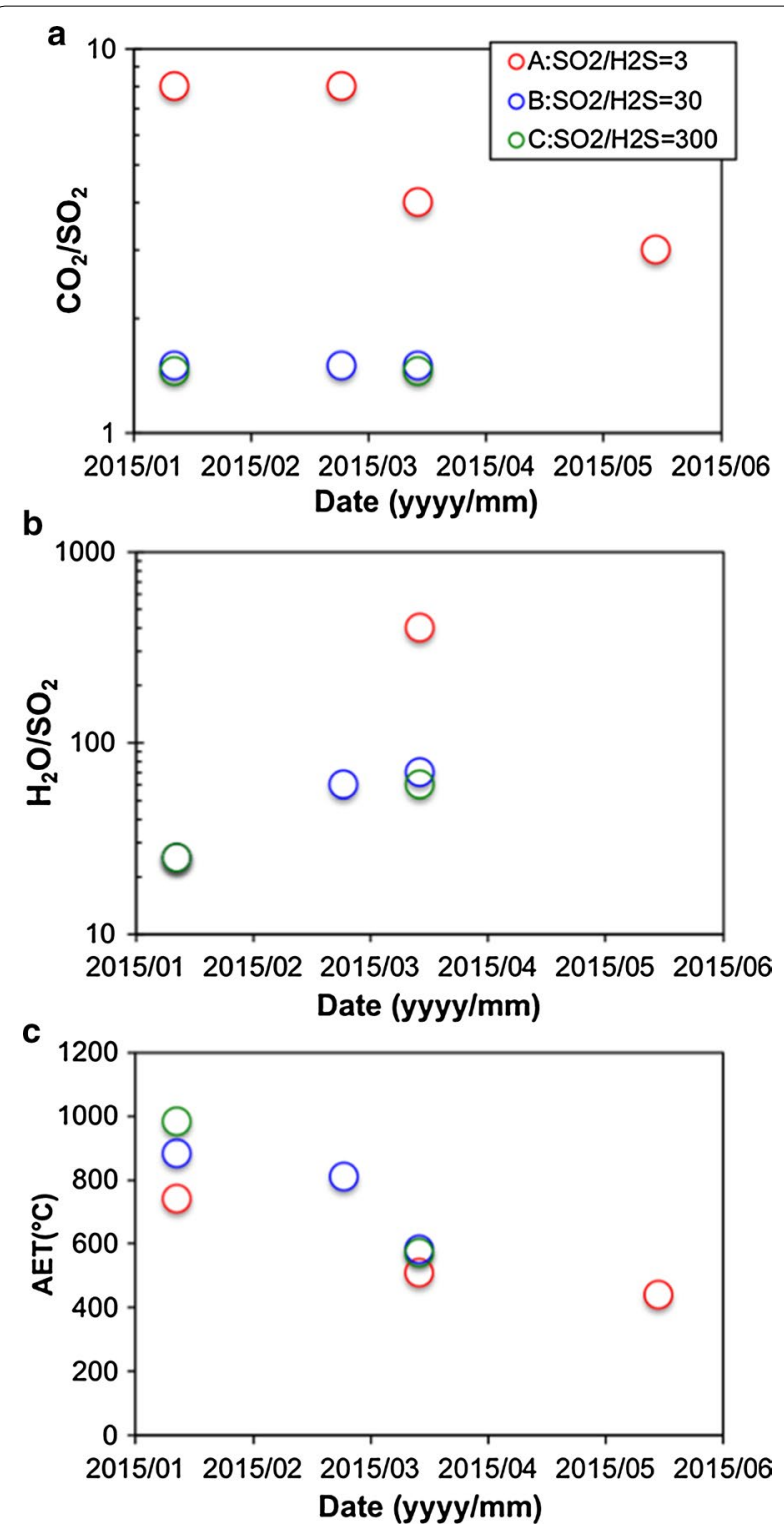

Fig. 11 Variation of the representative compositions of A series $\left(\mathrm{SO}_{2} /\right.$ $\mathrm{H}_{2} \mathrm{O}=3$; red), B series $\left(\mathrm{SO}_{2} / \mathrm{H}_{2} \mathrm{~S}=30\right.$; blue) and C-series $\left(\mathrm{SO}_{2} / \mathrm{H}_{2} \mathrm{~S}\right.$ = 300; green). a $\mathrm{CO}_{2} / \mathrm{SO}_{2}$ molar ratio, $\mathbf{b} \mathrm{H}_{2} \mathrm{O} / \mathrm{SO}_{2}$ molar ratio, and $\mathbf{d}$ apparent equilibrium temperature

the conduit magma convection (Kazahaya et al. 1994; Shinohara 2008). The conduit magma convection is likely the mechanism of the persistent degassing at the Nakadake cone. This hypothesis is supported by observation of clear glass shards in the lake sediment and in the products of small eruptions from the lake, implying degassing of a molten magma near surface (Miyabuchi et al. 2008; Miyabuchi and Terada 2009). The large $\mathrm{SO}_{2}$ fluxes of $1000-3000 \mathrm{t} / \mathrm{d}$ were measured during the eruptive period (Fukuoka Regional Headquarters, Japan
Meteorological Agency 2016). The erupting magma contributes only a small portion of the $\mathrm{SO}_{2}$ degassing and the major amount is derived by the conduit magma convection. $2 \times 10^{6}$ tons of ash was discharged during the early 70 days of the eruptive period (Yokoo and Miyabuchi 2015), and the total $\mathrm{SO}_{2}$ discharged during the same period is calculated as $1.4 \times 10^{5}$ tons, taking an average of $2000 \mathrm{t} / \mathrm{d}$. The $\mathrm{S}$ content of melt inclusions in andesitic scoria erupted on November 29, 2014, ranges from 0.008 to $0.036 \mathrm{wt} \%$ (Saito et al. 2017). Using the maximum $\mathrm{S}$ content, we can calculate the minimum estimate of the magma which supplied the $\mathrm{SO}_{2}$ as $2 \times 10^{8}$ tons, that is 100 times larger than the amount of the erupted magma. Dissolved volatiles in the erupted magma contribute only $1 \%$ of the gas emission, and $99 \%$ of the gases are derived from a magma convecting in the conduit or by bubbles already existed in a magma chamber where the melt inclusions formed.

Variation of the gas composition observed on January 12,2015 , is caused by a variation of gas-magma equilibrium pressure, such as ranging from 20 to $0.2 \mathrm{MPa}$ (Fig. 12a). During magma ascent, bubbles form and grow with decompression. In the early stage of bubble formation, the gas phase is likely in chemical equilibrium with the magma because of rapid chemical reactions under a magmatic temperature. Bubbles ascend relative to the magma by their buoyancy, and the bubble ascent rate increases with the bubble size. Rapid ascent of a large bubble reduces chemical interaction of the gas phase with the magma and finally loses the interaction. The gas-magma equilibrium pressure estimated from the gases discharged to the surface implies a pressure where the gas phase lost chemical interaction with the magma. Thermal diffusivity is larger than chemical diffusivity and thermal interaction will continue even after cessation of chemical interaction, but will be stopped by a very large bubble ascent rate, which causes cooling by the adiabatic expansion of bubbles. Lower AETs are obtained for the composition with higher equilibrium pressures. A high equilibrium pressure implies rapid bubble ascent that started at the high pressure that likely causes a large bubble ascent rate, resulting in a large degree of the adiabatic cooling. During the early measurement by 10:20 on January 12,2015 , the $\mathrm{CO}_{2} / \mathrm{SO}_{2}$ ratios are split into two values of two and eight (Fig. 4a). The two distinct ratios rather than scattering between the two ratios suggest two distinct bubble sources at different depth rather than a bubble ascent from variable depth.

The gas-magma separation at near atmospheric pressure is suggested from the composition $C$ and can be caused by degassing at the top of the convecting magma in a conduit. The bubbles ascend through the convecting magma column and caused the composition variation. 


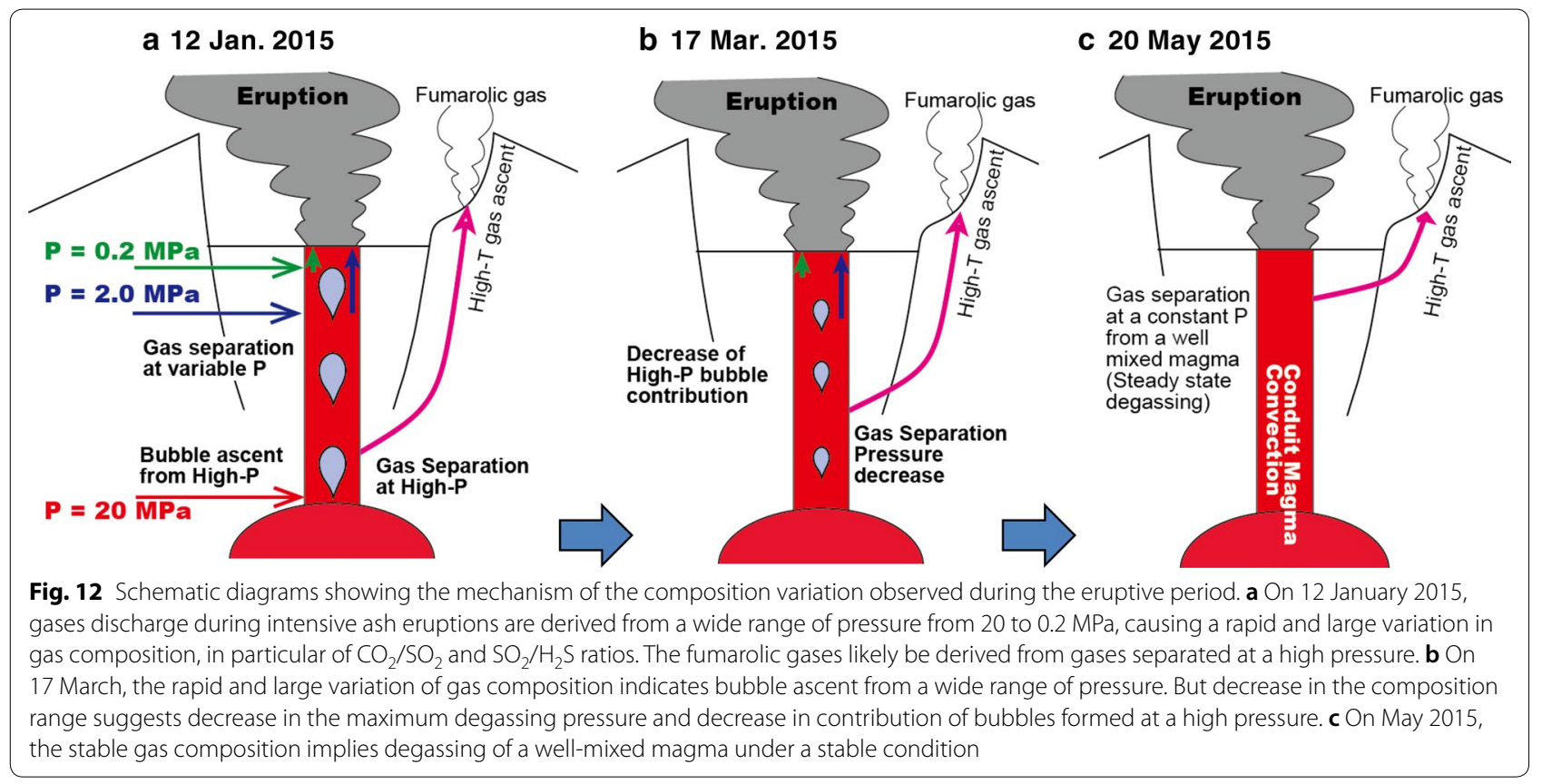

The rapid expansion of bubbles near surface may cause explosions. However, we could not find a clear correlation between observation of high $\mathrm{CO}_{2} / \mathrm{SO}_{2}$ ratios and occurrence of explosions. The plume which we measured reached to the crater rim with drifting by the wind, and the observed composition may not correspond to composition of each bubble but is likely an average composition of multiple bubbles and surface degassing.

The variations of $\mathrm{CO}_{2} / \mathrm{SO}_{2}$ and $\mathrm{SO}_{2} / \mathrm{H}_{2} \mathrm{~S}$ ratios of February 25 and March 17, 2015, are modeled as the result of gas emission from various gas-magma equilibrium pressures by assuming that those ratios are similar to the representative compositions on January 12, 2015. On 25 February and 17 March, the large $\mathrm{CO}_{2} / \mathrm{SO}_{2}$ and small $\mathrm{SO}_{2} / \mathrm{H}_{2} \mathrm{~S}$ ratios are obtained only with low concentration plumes (Figs. 9, 10). Plume concentration is not a direct measure of gas flux but tends to be small when flux is small. The low plume concentration suggests that contribution of bubbles with a larger equilibrium pressure decreased after January 12, 2015. The smaller $\mathrm{CO}_{2} / \mathrm{SO}_{2}$ ratio of the composition $\mathrm{A}$ " compared to the composition A suggests that the maximum equilibrium pressure is smaller on 17 March than on 12 January (Fig. 12b). The $\mathrm{H}_{2} / \mathrm{SO}_{2}$ and $\mathrm{H}_{2} \mathrm{O} / \mathrm{SO}_{2}$ ratios increased and the AET decreased with time (Fig. 11), and these changes can be caused by increase in near-surface mixing of a hydrothermal solution with time.

The $\mathrm{CO}_{2} / \mathrm{SO}_{2}$ and $\mathrm{SO}_{2} / \mathrm{H}_{2} \mathrm{~S}$ ratios of May 19 and 20, 2015 , indicate that the gases equilibrated with the magma at a constant and intermediate pressure are discharged. The compositions with the low equilibrium pressure (e.g., compositions C, C' and C") were not observed in May, suggesting that the pressure at the top of the convecting magma increased to the intermediate pressure. We do not have a clear model to explain the mechanism of the pressure increase at the top of the magma column. The pressure increase at the top of the convecting magma column will reduce gas volume proportion in the magma, then reduce fragmentation of magmas by bubble expansion and may lead to cessation of the ash eruption soon after.

Volcanic gases are discharged not only from the main vent but also from the fumaroles at the southern crater rim (Fig. 2). The fumarole plumes are often pale transparent in contrast to the white opaque plume of the main vent, indicating a higher temperature of the fumarolic gas than the main vent gas. A high temperature at the source prevents water condensation in a plume by a mixing with the air and often forms a transparent plume (Matsushima and Shinohara 2006). Size of the plumes derived from the fumaroles look smaller than that from the main vent but in the same order of magnitude. The observed composition variation likely reflects mainly what occurred at the main vent but also includes contribution of the fumarolic gases. The gases equilibrated as low pressures (the compositions $C$ and C") are less likely discharged from the fumaroles but likely from the main vent where near surface distribution of the magma is inferred from the continuous ash eruption with frequent Strombolian activity. The gases equilibrated at a high pressure (e.g., the composition A, and A") can leak from the magma conduit to the surroundings to be discharged at the fumaroles (Fig. 12). A significant cooling of gas temperature from the magma 
temperature was estimated for the composition A and is attributed to the adiabatic expansion of bubbles. The gas ascent to the fumaroles, however, less likely causes the significant cooling, because the gas ascent through channels is an isenthalpic process, whereas the free expansion of bubbles in a magma is isentropic process. At present, contribution of the fumarolic gases to the observed composition is not clear. We need separate measurement of the plumes derived from the two sources by applying a drone or FT-IR (Allard et al. 2005; Mori et al. 2016).

The large $\mathrm{SO}_{2}$ fluxes of $1000-3000 \mathrm{t} / \mathrm{d}$ are measured during the eruptive period but similarly large fluxes of $1000-2000 \mathrm{t} / \mathrm{d}$ are measured during the pre-eruptive and post-eruptive periods, implying that the large $\mathrm{SO}_{2}$ flux, therefore the large magma convection rate, is not a direct cause of the eruptions. The volcanic gas compositions measured during the eruptive period showed large and rapid variation, in particular the $\mathrm{CO}_{2} / \mathrm{SO}_{2}$ and $\mathrm{SO}_{2} / \mathrm{H}_{2} \mathrm{~S}$ ratios varied from 1.5 to 8 , and from 4 to 100 , respectively, within a few minute (Fig. 4a, b). The composition variation is interpreted as the result of degassing at variable pressure, likely caused by rapid ascent of large bubbles. Recent gas composition measurements during Strombolian and lava fountaining eruptions at Stromboli and Etna volcanoes demonstrated that these eruptions are driven by rapid ascent of bubbles formed at a large depth (Aiuppa et al. 2009; Allard et al. 2005; Burton et al. 2007). Similarly the ash eruptions at the Nakadake volcano can be driven by the rapid bubble ascent. The composition variation suggesting the large degassing pressure variation becomes less significant with time and disappeared in May, 2015, just before the end of the eruptive activity. This temporal variation is consistent with the idea of bubble-driven eruption. Occurrence of each explosion, however, did not directly correlate with the rapid composition variation. If the eruption is driven by a bubble-rich magma, bulk gas composition should become more $\mathrm{CO}_{2}$-rich with increasing eruption intensity. However, we could not estimate an average composition of gases on each day and cannot evaluate variation of bulk gas composition, such as a correlation of the $\mathrm{CO}_{2} /$ $\mathrm{SO}_{2}$ ratio of the bulk gas and intensity of the eruptive activity. We need further detailed data set to conclude the bubble-driven eruption at the Nakadake crater.

\section{Degassing process during the quiet period}

During the quiet period, the lake gas and the fumarolic gas have different and variable compositions (Fig. 3). The composition differences and variation might be caused by differentiation between these gases and with the crater lake water. $\mathrm{HCl}$ and $\mathrm{H}_{2} \mathrm{~S}$ in the lake gas are largely controlled by entrapment by the crater lake water. The $\mathrm{CO}_{2} /$ $\mathrm{SO}_{2}$ ratio of these gases is contrasting; the lake gases have smaller ratios of 0.34-2.6 than those of fumarolic gases of 1.7-10 with small overlap. The $\mathrm{CO}_{2} / \mathrm{SO}_{2}$ ratios of these gases show a symmetric variation with a central value of about two (Fig. 3a). These features indicate that these gases are derived from a single source with the $\mathrm{CO}_{2} / \mathrm{SO}_{2}$ ratio of two. Shinohara et al. (2015b) interpreted that the fumarolic gas is a mixture of a magmatic gas and a $\mathrm{CO}_{2}$-rich vapor separated from an underground hydrothermal system, and the gases remained in a liquid phase in the hydrothermal system are the source of the lake gases. A wide range of the $\mathrm{CO}_{2} / \mathrm{SO}_{2}$ ratios was observed during the eruptive period and is modeled as the result of variable degassing pressure. The variable degassing pressure during eruptions might be caused by rapid ascent of bubbles from variable depth. The observed range of the $\mathrm{CO}_{2} / \mathrm{SO}_{2}$ ratio during the eruptive periods is similar to that of the lake and the fumarolic gases during the quiet period. The wide range of the $\mathrm{CO}_{2} / \mathrm{SO}_{2}$ ratios observed during the quiet period can be also caused by variation of the degassing pressure. The fumarolic gas with the large $\mathrm{CO}_{2} / \mathrm{SO}_{2}$ ratio can be derived by a gas leakage from a magma at a great depth, and the lake gas with the small $\mathrm{CO}_{2} / \mathrm{SO}_{2}$ ratio is the gases discharged by a low-pressure degassing of the magma which already lost the $\mathrm{CO}_{2}$-rich bubbles to the fumarolic gases. Variation of the gasmagma separation to the fumarolic gases can cause the temporal variation of the $\mathrm{CO}_{2} / \mathrm{SO}_{2}$ ratios.

Similar $\mathrm{CO}_{2} / \mathrm{SO}_{2}$ ratios were measured for the lake and fumarolic gases in October 2004 and October 2008 (Fig. 3a). In these cases, the same magmatic gas separated from the same depth may be supplied to both the lake and fumarolic gases. The composition difference of these gases is mainly caused by low-temperature differentiation in the lake, and the fumarolic gas likely retains features of the magmatic gas composition. The $\mathrm{H}_{2} \mathrm{O} / \mathrm{SO}_{2}$ ratios of the fumarolic gas do not show clear temporal variation with an average of $53 \pm 22$ (Fig. 3b). This value is larger but with some overlap with the ratios of $30 \pm 13$ obtained during the most active eruptive period on January 12,2015 . The central value of the lake and fumarolic gas $\mathrm{CO}_{2} / \mathrm{SO}_{2}$ ratios is two, and likely represents the bulk gas composition discharged from the volcano during the quiet period. This value is similar to that observed in May 2015 when a single composition was observed. The similarity of the bulk gas compositions implies a small variation of volatile contents in the magmas supplied during the quiet period and the eruptive period, and does not agree with the idea that the ash eruption was driven by a bubble-rich magma. However, the similarity of the bulk gas $\mathrm{CO}_{2} / \mathrm{SO}_{2}$ ratio during the active eruptive period was not confirmed because of the lack of the bulk composition estimate during the most active eruptive period. 


\section{Conclusion}

Variation of volcanic gas composition was measured by Multi-GAS during the eruptive period in 2014-2015 and during the quiet period preceding the eruption. Volcanic gas composition during the eruptive period is characterized by its rapid and large variation. On January 12, 2015, gas compositions were measured during the intensive ash eruption with intermittent Strombolian activity. The $\mathrm{CO}_{2} / \mathrm{SO}_{2}$ and $\mathrm{SO}_{2} / \mathrm{H}_{2} \mathrm{~S}$ ratios varied rapidly during a few hours of the measurements, within the ranges from 1.5 to 8 and from 3 to 300, respectively. The variation shows a well-constrained correlation between two end-member compositions; the one is $\mathrm{CO}_{2} / \mathrm{SO}_{2}=8$ and $\mathrm{SO}_{2} / \mathrm{H}_{2} \mathrm{~S}=3$ and the other is $\mathrm{CO}_{2} / \mathrm{SO}_{2}=1.5$ and $\mathrm{SO}_{2} / \mathrm{H}_{2} \mathrm{~S}=300$. These contrasting compositions can be caused by a large variation of the gas-magma equilibrium pressure ranging from 0.2 to $20 \mathrm{MPa}$. The rapid and large composition variation is likely the results of frequent bubble ascent from variable depth. The AETs calculated at one atmosphere range from 770 to $990{ }^{\circ} \mathrm{C}$. The high AETs are similar to that of magma and are consistent with degassing from the erupting magma. The low AETs are calculated for the gases with larger $\mathrm{CO}_{2} / \mathrm{SO}_{2}$ ratios and are attributed to cooling by adiabatic expansion of bubbles caused by rapid ascent. The rapid and large variation of the $\mathrm{CO}_{2} / \mathrm{SO}_{2}$ and $\mathrm{SO}_{2} / \mathrm{H}_{2} \mathrm{~S}$ ratios were observed also in the later period in February and March, but the maximum $\mathrm{CO}_{2} / \mathrm{SO}_{2}$ ratio decreased to 4 on March 17, 2015, suggesting decrease in the maximum degassing pressure. Increase in a mixing of hydrothermal solution to the main vent plume is suggested based on the $\mathrm{H}_{2} \mathrm{O} / \mathrm{SO}_{2}$ ratio increase and the AETs decrease from January to March. On May 19 and 20,2015 , the last day of the eruptive period, composition variation was not observed during the measurements and a single gas composition with intermediate $\mathrm{CO}_{2} / \mathrm{SO}_{2}$ and $\mathrm{SO}_{2} / \mathrm{H}_{2} \mathrm{~S}$ ratios of 3 and 5 , respectively, were obtained.

Conditions of volcanic gas degassing during the eruptive period is interpreted as follows based on the volcanic gas composition data. During the intensive ash eruption, a rapid and large gas composition variation is caused by frequent ascent of bubbles from various depth. The bubble ascent from various depth continued during the eruptive period, but contribution of the bubbles derived from the high pressure decreased with time. Contribution of a hydrothermal solution also increased. At the end of the eruptive period, degassing condition becomes stable without contribution of bubbles from various depth, resulting in a stable volcanic gas composition. The correlation between evolution of eruptive activities and gas supply conditions is consistent with the idea of an eruption driven by $\mathrm{CO}_{2}$-rich bubbles supplied from a great depth that has been proposed for Strombolian and lava fountaining eruptions. However, some data do not clearly support this idea, such as the lack of time correspondence between each explosion with the time of large $\mathrm{CO}_{2} / \mathrm{SO}_{2}$ ratio peaks. Average $\mathrm{CO}_{2} / \mathrm{SO}_{2}$ ratios also did not show significant difference between those during the eruptive period and the quiet period. Further investigations are necessary to test this hypothesis for the ash eruption.

\section{Additional files}

Additional file 1: Fig. S1. Variation of plume gas concentrations measured by Multi-GAS during the eruptive period. The measurement date and sequence are shown on the top left.

Additional file 2. Table S1: Volcanic gas species concentration at major $\mathrm{SO}_{2}$ peaks in the plume measured on 12 January, 2015. Table S2 Volcanic gas species concentration at major $\mathrm{SO}_{2}$ peaks in the plume measured on 25 February, 2015. Table S3 Volcanic gas species concentration at major $\mathrm{SO}_{2}$ peaks in the plume measured on 17 March, 2015.

\section{Abbreviations}

AET: Apparent equilibrium temperature; FT-IR: Fourier transform infrared absorption spectroscopy; QFM: Quartz-Fayalite-Magnetite.

\section{Authors' contributions}

HS and RK performed Multi-GAS measurements, and AY performed geophysical and visual observation of the volcanic activity. All authors contributed to discussion and preparation of the manuscript. All authors read and approved the final manuscript.

\section{Author details \\ ${ }^{1}$ Geological Survey of Japan, National Institute of Advanced Industrial Science and Technology, 1-1-1 Higashi, Tsukuba, Ibaraki 305-8567, Japan. ${ }^{2}$ Aso Vol- canological Laboratory, Kyoto University, Sakanashi, Aso, Kumamoto 869-2611, Japan.}

\section{Acknowledgements}

We thank Drs. T. Kagiyama, T. Ohkura, M. Utsugi, S. Yoshikawa, H. Inoue, S. Komori, Y. Miyabuchi, N. Geshi and H. Hoshizumi for their support during the fieldwork, and Ms. M. Someya for sample analyses.

\section{Competing interests}

The authors declare that they have no competing interests.

\section{Funding}

This work is partially supported by Grants-in Aid for Scientific Research (KAKENHI) 22340130, 25287115 and 17H02955 from the Japan Society for the Promotion of Science (JSPS) to HS.

\section{Publisher's Note}

Springer Nature remains neutral with regard to jurisdictional claims in published maps and institutional affiliations.

Received: 28 March 2018 Accepted: 5 September 2018

Published online: 21 September 2018

\footnotetext{
References

Aiuppa A, Inguaggiato S, McGonigle AJS, O'Dwyer M, Oppenheimer C, Padgett MJ, Rouwet D, Valenza M (2005) $\mathrm{H}_{2}$ S fluxes from Mt. Etna, Stromboli, and Vulcano (Italy) and implications for the sulfur budget at volcanoes. Geochim Cosmochim Acta 69:1861-1871

Aiuppa A, Federico C, Giudice G, Giuffrida G, Guida R, Gurrieri S, Liuzzo M Moretti R, Papale P (2009) The 2007 eruption of Stromboli volcano: insights from real-time measurement of the volcanic gas plume $\mathrm{CO}_{2} / \mathrm{SO}_{2}$ ratio. J Volcanol Geotherm Res 182:221-230
} 
Aiuppa A, Bitetto M, Francofonte V, Valasquez G, Parra C, Giudice G, Liuzzo M, Moretti R, Moussallam Y, Peters N, Tamburello G, Vaderrama O, Curtis A (2017) $\mathrm{A} \mathrm{CO}_{2}$-gas precursor to the March 2015 Villarrica volcano eruption. Geochem Geophys Geosys. https://doi.org/10.1002/2017GC006892

Allard P (2010) A CO $\mathrm{CO}_{2}$-rich gas trigger of explosive paroxysms at Stromboli basaltic volcano, Italy. J Volcanol Geotherm Res 189:363-374

Allard P, Burton M, Muré F (2005) Spectroscopic evidence for a lava fountain driven by previously accumulated magmatic gas. Nature 433:407-410

Burgisser A, Oppenheimer C, Alletti M, Kyle PR, Scaillet B, Carrol MT (2012) Backward tracking of gas chemistry measurements at Erebus volcano. Geochem Geophys Geosyst. https://doi.org/10.1029/2012GC004243

Burgisser A, Alletti M, Scaillet B (2015) Simulating the behavior of volatiles belonging to the $\mathrm{C}-\mathrm{O}-\mathrm{H}-\mathrm{S}$ system in silicate melts under magmatic conditions with the software D-compress. Comput Geosci 79:1-14

Burton M, Allard P, Muré F, La Spina A (2007) Magmatic gas composition reveals the source depth of slug-driven Strombolian explosive activity. Science 317:227-230

Capaccioni B, Rouwet D, Tassi F (2016) HCl degassing from extremely acidic crater lakes: preliminary results from experimental determinations and implications for geochemical monitoring. In: Ohba T, Capaccioni B, Caudron C (eds) Geochemistry and geophysics of active volcanic lakes, vol 427. Geological Society of London Spe Publ, London. https://doi. org/10.1144/sp437.12

de Moor M, Aiuppa A, Avard G, Welmann H, Dunbar N, Muller C, Tamburello G, Giudice G, Liuzzo M, Moretti R, Conde V, Galle B (2016) Turmoil at Turrialba volcano (Costa Rica): degassing and eruptive processes inferred from high-frequency gas monitoring. J Geophys Res Solid Earth. https://doi. org/10.1002/2016JB013150

Edmonds M (2008) New geochemical insights into volcanic degassing. Philos Trans R Soc A 366:4559-4579

Fukuoka Regional Headquarters, Japan Meteorological Agency (2016) Volcanic activity of Asosan volcano-October 2014-February 2015 (in Japanese). Reports of Coordinating Committee for Prediction of Volcanic Eruption, pp 166-186. http://www.data.jma.go.jp/svd/vois/data/tokyo/STOCK/ kaisetsu/CCPVE/Report/120/kaiho 120 23.pdf

Giggenbach WF (1987) Redox processes governing the chemistry of fumarolic gas discharges from White Island, New Zealand. Appl Geochem 2:143-161

Giggenbach WF (1996) The origin and evolution of fluids in magmatic-hydrothermal systems. In: Barnes HL (ed) Geochemistry of hydrothermal ore deposits, 3rd edn. John Wiley, New York, pp 737-796

Holloway J, Blank J (1994) Application of experimental results to C-O-H species in natural melts. Rev Mineral 30:187-230

Ikebe S, Watanabe I, Miyabuchi Y (2008) The sequence and style of the 19881995 eruptions of Nakadake Aso volcano, Kyushu, Japan. Bull Volcanol Soc Jpn 53:15-33 (in Japanese with English abstract)

Kawakatsu H, Kaneshima S, Matsubayashi H, Ohminato T, Sudo Y, Tsutsui T, Yamasato H, Ito H, Legrand D (2000) Aso94: Aso seismic observation with broadband instruments. J Volcanol Geotherm Res 101:129-154

Kazahaya K, Shinohara H, Saito G (1994) Excess degassing of Izu-Oshima volcano: magma convection in a conduit. Bull Volcanol 56:207-216

La Spine A, Burton M, Allard P, Alparone S, Muré F (2015) Open-path FTIR spectroscopy of magma degassing processes during eight lava fountains on Mount Etna. Earth Planet Sci Lett 413:123-134

Marumoto K, Sudo Y, Nagamatsu Y (2017) Collateral variations between the concentrations of Mercury and other water soluble ions in volcanic ash samples and volcanic activity during the 2014-2016 eruptive episodes at Aso volcano, Japan. J Volcanol Geotherm Res 341:149-157

Matsuo S (1960) On the origin of volcanic gases. J Earth Sci Nagoya Univ 8:222-245

Matsushima N, Shinohara H (2006) Visible and invisible volcanic plumes. Geophys Res Lett. https://doi.org/10.1029/2006GL026506

Miyabuchi Y, Terada A (2009) Subaqueous geothermal activity of acidic crater lake revealed by lacustrine sediments, Aso volcano, Japan. JVolcanol Geotherm Res 187:140-145

Miyabuchi Y, Ikebe S, Watanabe K (2008) Geological constraints on the 2003-2005 ash emissions from the Nakadake crater lake, Aso volcano, Japan. J Volcanol Geotherm Res 178:169-183

Moretti R, Papale P, Ottonello G (2003) A model for the saturation of C-O-H-S fluids in silicate melts. In: Oppenheimer C, Pyle D, Barclay J (eds) Volcanic Degassing, vol 213. Gol Soc London Sp Pul, London, pp 81-101
Mori T, Hashimoto T, Terada A, Kazahaya R, Shinohara H, Tanaka R (2016) Volcanic plume measurements using a UAV for the 2014 Mt. Ontake eruption. Earth Planets Space. https://doi.org/10.1186/s40623-016-0418-0

Ohba T, Hirabayashi J, Yoshida M (1994) Equilibrium temperature and redox state of volcanic gas at Unzen volcano, Japan. J Volcanol Geotherm Res 60:263-272

Ohsawa S, Sudo Y, Mawatari H, Shimoda G, Utsugi M, Amita K, Yoshikawa S, Yamada M, Iwakura K, Onda Y (2003) Some geochemical features of Yudamari crater lake, Aso volcano, Japan. Geotherm Res Rep Kyushu Univ 12:62-65 (in Japanese with English abstract)

Ohsawa S, Saito T, Yoshikawa S, Mawatari H, Yamada M, Amita K, Takamatsu N, Sudo Y, Kagiyama T (2010) Color change of lake water at the active crater lake of Aso volcano, Yudamari, Japan: is it in response to change in water quality induced by volcanic activity? Limnology 11:207-215

Ono K, Watanabe K (1985) Geological map of Aso volcano 1:50,000. geological map of volcanoes 4. Geological Survey of Japan (in Japanese with English abstract)

Ono K, Watanabe K, Hoshizumi H, Ikebe S (1995) Ash eruption of the Nakadake crater, Aso volcano, southwestern Japan. J Volcanol Geotherm Res 66:137-148

Saito G, Ishizuka O, Ishizuka Y, Hoshizumi H (2017) Volatile content of magmas of the 2014, 1989, and 1979 eruptions of Naka-dake, Aso volcano based on melt inclusion analyses. In: JpGU 2017 abstract, SVC47-P20

Shinohara H (2005) A new technique to estimate volcanic gas composition: plume measurements with a portable multi-sensor system. J Volcanol Geotherm Res 143:319-333

Shinohara H (2008) Excess degassing from volcanoes and its role on eruptive and intrusive activity. Rev Geophys 46:RG4005. https://doi. org/10.1029/2007rg000244

Shinohara H, Witter J (2005) Volcanic gases emitted during mild Strombolian activity of Villarrica volcano. Chile. Geophys Res Lett 32:L20308. https:// doi.org/10.1029/2005GL024131

Shinohara H, Kazahaya K, Saito G, Matsushima N, Kawanabe Y (2002) Degassing activity from Iwodake rhyolitic cone, Satsuma-Iwojima volcano, Japan: formation of a new degassing vent, 1990-1999. Earth Planets Space 54:175-185. https://doi.org/10.1186/BF03353017

Shinohara H, Matsushima N, Kazahaya K, Ohwada M (2011) Magma-hydrothermal system interaction inferred from volcanic gas measurements obtained during 2003-2008 at Meakandake volcano, Hokkaido, Japan. Bull Volcanol 73:409-421

Shinohara H, Ohminato T, Takeo M, Tsuji H, Kazahaya R (2015a) Monitoring of volcanic gas composition at Asama volcano, Japan, during 2004-2014. J Volcanol Geotherm Res 303:199-208

Shinohara H, Yoshikawa S, Miyabuchi Y (2015b) Degassing activity of a volcanic crater lake: volcanic plume measurements at the Yudamari crater lake, Aso volcano, Japan. In: Rouwet D, Christenson B, Tassi F, Vandemeulebrouck J (eds) Volcanic lakes. Springer, Berlin. https://doi.org/10.1007/9783-642-36833-2_8

Shinohara H, Geshi N, Yokoo A, Ohkura T, Terada A (2018) Salt shell fallout during the ash eruption at the Nakadake crater, Aso volcano, Japan: evidence of an underground hydrothermal system surrounding the erupting vent. Earth Planets Space 70:46. https://doi.org/10.1186/s40623-018-0798-4

Sudo Y, Tsutsui T, Nakaboh M, Yoshikawa M, Yoshikawa S, Inoue H (2006) Ground deformation and magma reservoir at Aso volcano: location of deflation source derived from long-term geodetic surveys. Bull Volcanol Soc Jpn 51:291-309 (in Japanese with English abstract)

Symonds R, Rose W, Bluth G, Gerlach T (1994) Volcanic-gas studies: methods. results, and applications. Rev Mineral 30:1-66

Terada A, Hashimoto T (2017) Variety and sustainability of volcanic lakes: response to subaqueous thermal activity predicted by a numerical model. J Geophys Res Solid Earth. https://doi.org/10.1002/2017JB014387

Tsunogai U, Kaminura K, Anzai S, Nakagawa F, Komatsu DD (2011) Hydrogen isotopes in volcanic plumes: tracers for remote temperature sensing of fumaroles. Geochim Cosmochim Acta 75:4531-4546

Witham F, Blundy J, Hohn S, Lesne P, Dixon J, Churakov S, Botcharnikov R (2012) SolEx: a model for mixed COHSCl-volatile solubilities and exsolved gas compositions in basalt. Comput Geosci 45:87-97

Yokoo A, Miyabuchi Y (2015) Eruption at the Nakadake 1st crater of Aso volcano started in November 2014. Bull Volcanol Soc Jpn 60:275-278 (in Japanese) 